\title{
Growth factors from bovine milk and colostrum: composition, extraction and biological activities
}

\author{
Sylvie F. GAUTHIER ${ }^{a *}$, Yves POULIOT ${ }^{\mathrm{a}}$, Jean-Louis MAUBOIS ${ }^{\mathrm{b}}$ \\ a Groupe STELA, Institut des Nutraceutiques et Aliments Fonctionnels (INAF), Université Laval, \\ Québec, Canada, G1K 7P4 \\ b UMR 1253, Science et Technologie du Lait et de l'Euf, Inra-Agrocampus Rennes, \\ 65 rue de Saint-Brieuc, 35042 Rennes Cedex, France
}

Received 13 November 2005 - Accepted 29 November 2005

\begin{abstract}
EGF, BTC, IGF-I, IGF-II, TGF- $\beta 1$, TGF- $\beta 2$, FGF1 and 2, and PDGF are the main growth factors present in bovine milk and colostrum. All of these growth factors are also found in human milk but at a lower concentration. The various compositional data reported in the literature vary greatly but it is evidenced that the day of lactation has the most important effect. Milk growth factors are characterized by a neutral to alkaline isoelectric point $(\mathrm{pI})$ and a molecular mass between $6400 \mathrm{~g} \cdot \mathrm{mol}^{-1}$ and $30000 \mathrm{~g} \cdot \mathrm{mol}^{-1}$. However, many of the growth factors are in a latent form, bound to high-molecular-mass proteins. Milk growth factors are resistant generally to pasteurization but disulfide reducing agents have been found to inactivate some species such as TGF- $\beta$ 's. The published data on bioavailability of milk growth factors are somewhat contradictory but it is generally accepted that they are resistant to gastric digestion and they can exert local and systemic effects on the gastrointestinal tract. Cation-exchange chromatography has been widely used for the extraction of milk growth factors because of the basic nature of these molecules. Membrane separations such as microfiltration (MF) have also been used successfully for the extraction of immunoglobulins and of some growth factors from colostrum, while ultrafiltration (UF) was successful only at separating IGF-I and IGF-II in whey. Milk growth factor extracts have been developed for various applications such as treatment of gastrointestinal disorders and skin diseases, wound healing, and induction of oral tolerance.
\end{abstract}

growth factors / colostrum / milk / whey / extraction process / biological activity

摘要 - 牛乳和牛初乳中生长因子的组成提取和生物活性。表皮生长因子 (EGF)、 $\beta$ 细胞素 (BTC)、胰岛素样生长因子 I (IGF-I)、胰岛素样生长因子 II (IGF-II)、转化生长因子 $\beta 1$ (IGF$\beta 1$ )、转化生长因子 $\beta 2$ (IGF- $\beta 2$ )、成纤维细胞生长因子 I (FGF1)、成纤维细胞生长因子 (FGF 2 ) 和血小板源性生长因子 (PDGF) 是存在于牛乳和牛初乳中的主要生长因子, 这些生长因子 也存在于人乳中, 但是浓度很低。许多文献报道这些生长因子在牛乳和初乳中组成的数据 差距非常大, 但是有一点可以达成共识的是哺乳天数对这些生长因子的影响很大。牛乳中 的生长因子是根据其等电点从中性到碱性来描述其特性, 这些生长因子的平均分子量在 $64000 \mathrm{~g} \cdot \mathrm{mol}^{-1} \sim 30000 \mathrm{~g} \cdot \mathrm{mol}^{-1}$ 之间。由于乳中许多生长因子与大分子的蛋白质结合在一起, 所以其活性是隐性的。通常牛乳中的生长因子是可以抵抗巴氏杀菌的，但有报道二硫化合 物类的还原剂能够抑制某些生长因子的活性, 如 TGF- $\beta$ ' $s$ 。有些文献报道的关于牛乳中生长 因子生物利用率的数据是相互矛盾, 但是普遍接受的观点是这些生长因子能够抵抗胃内消 化作用, 能够有效在胃肠道中定殖并能够起到改善胃肠道功能的作用。由于这些生长因子

\footnotetext{
* Corresponding author (通讯作者): Sylvie.Gauthier@aln.ulaval.ca
} 
是碱性化合物，因此阳离子交换色谱技术可以有效地用于牛乳中生长因子的提取。膜技术 如微滤 (MF) 已经成功地用于从初乳中提取免疫球蛋白和一些生长因子, 而超滤技术则可用 于分离乳清中的 IGF-I 和 IGF-II。牛乳生长因子提取物具有广泛应用领域, 如用于治疗胃肠 道紊乱、皮肤病以及促进伤口愈合等。

\section{生长因子 / 初乳 / 牛乳 / 乳清 / 提取过程 / 生物活性}

Résumé - Facteurs de croissance dans le lait et le colostrum bovins : composition, extraction et activités biologiques. Les principaux facteurs de croissance retrouvés dans le lait bovin et le colostrum sont : EGF, BTC, IGF-I, IGF-II, TGF- $\beta 1$, TGF- 32 , FGF1 et 2 , ainsi que PDGF. Les concentrations de ces facteurs de croissance dans le lait bovin sont supérieures à celles rapportées pour le lait humain. Les teneurs en facteurs de croissance retrouvées dans la littérature varient selon les auteurs mais il se dégage malgré tout que le jour de la collecte de l'échantillon au cours de la période de lactation représente le facteur de variation le plus important. Les facteurs de croissance du lait se caractérisent par un point isoélectrique $(\mathrm{pI})$ alcalin et une masse moléculaire se situant entre $6400 \mathrm{~g} \cdot \mathrm{mol}^{-1}$ et $30000 \mathrm{~g} \cdot \mathrm{mol}^{-1}$. Plusieurs des facteurs de croissance sont cependant présents dans le lait sous forme latente, souvent liés à des protéines de masses moléculaires élevées. Les facteurs de croissance du lait sont résistants à la pasteurisation alors que certains d'entre eux, comme les TGF- $\beta$ 's, peuvent être inactivés par des substances réductrices des ponts disulfures. Des données parfois contradictoires ont été publiées au sujet de la biodisponibilité des facteurs de croissance, mais il est généralement accepté que les facteurs de croissance résistent à la digestion gastrique et peuvent exercer des effets locaux et systémiques au niveau du tractus gastrointestinal. La chromatographie d'échange cationique a été largement utilisée pour l'extraction des facteurs de croissance, et ce, en raison de leur nature cationique. Les séparations membranaires comme la microfiltration (MF) ont été utilisées avec succès pour séparer des immunoblobulines et quelques facteurs de croissance du colostrum. L'ultrafiltration (UF) n'a été utilisée avec succès que dans la séparation de l'IGF-I et IGF-II présents dans le lactosérum. Des extraits de facteurs de croissance ont été développés pour diverses applications telles le traitement de désordres gastrointestinaux et de maladies de la peau, la cicatrisation et l'induction de la tolérance orale.

\section{facteurs de croissance / colostrum / lait / lactosérum / extraction / activité biologique}

List of abbreviations: ALS: acid labile subunit; BTC: betacellulin; ECM: extracellular matrix; EGF: epidermal growth factor; FGF: fibroblast growth factor; G-CSF: granulocyte colonystimulating factor; GROS- $\alpha$ : growth-related peptide alpha; IFN:interferon; IGF: insulin-like growth factor; IGFBPs: IGF binding proteins; IL: interleukine; LAP: latent associated peptide; LTBP: latent TGF- $\beta$ binding protein; $\alpha_{2}-\mathrm{M}$ : alpha $a_{2}$-macroglobulin; MCP: monocyte chemotactic protein; M-CSF: macrophage colony-stimulating factor; OPN: osteopontin; PDGF: platelet-derived growth factor; RANTES: regulated upon activation, normal $\mathrm{T}$ cell expressed and presumably secreted; TGF: transforming growth factor; TNF: tumor necrosis factor; VEGF: vascular endothelial growth factor; UF/DF: ultrafiltration/diafiltration.

\section{INTRODUCTION}

Reviewing the literature on the extraction of growth factors from bovine milk is complicated by the lack of distinction between hormones, cytokines and specifically named growth factors. All of these molecules are important for the growth, maturation or repair of different cell types in the neonate and/or adult. Moreover, all of these growth-promoting factors are signaling molecules released by cells to communicate with each other.

Hormones can be described as substances that are released into the extracellular medium by the cells of one tissue, to be carried to a new site of action (endocrine function), where they induce a specific response. Generally, they are not included in the growth factor families. The distinction between cytokines and growth factors is more arbitrary since certain growth factors 
(e.g. TGF- $\beta$ ) are also considered as cytokines by many authors [142, 153].

Cytokines are proteins or glycoproteins, which are produced by many cell types and have profound bioactive effects, in a very minute range of concentration (10 to $1000 \mathrm{pg} \cdot \mathrm{mL}^{-1}$ ), on other cells within a short distance, or often even on the cells from which they originate. Hence, cytokine effects tend to be local, where they are involved in autocrine or paracrine functions. This definition also includes molecules which are principally responsible for the coordination of the immune response (enhance or suppress immunity), and generally include the interleukins (IL) series, tumour necrosis factors (TNF) and interferons (IFN).

Growth factors are proteins or polypeptides that bind to receptors on the cell surface, with the primary result of activating cellular proliferation and/or differentiation. Many growth factors are relatively versatile, stimulating cellular division in numerous different cell types, while others are specific to a particular cell type. Some growth factors, such as TGF- $\beta$, can also inhibit the growth of specific cells (macrophage and lymphocyte). As cytokines, growth factors are involved in autocrine or paracrine functions.

Given the scope of this review, and based on the data available which have evidenced the presence of growth factors in bovine colostrum or milk extracts, we will be considering the following molecules as growth factors: EGF, BTC, IGF-I and IGF-II, TGF$\beta 1$ and TGF- $\beta 2$, FGF1 and 2 , and PDGF. Others such as erythropoietin $\left(11 \mathrm{mU} \cdot \mathrm{mL}^{-1}\right.$ in breast milk according to Kling et al. [110]), which lengthens the small intestine of the neonate [100] and for which a specific intestinal receptor has been identified, will not be considered because of a lack of sufficient information on them.

\section{GROWTH FACTORS IN COLOS- TRUM, MILK AND WHEY}

The presence of factors with growthpromoting or growth-inhibitory activity for many different cell types was first demon- strated in human colostrum and milk during the 1980's [34, 40, 41, 93, 107, 172, 173, $198,217]$, and then in bovine colostrum, milk and whey $[7,13,14,23,31,32,40,44$, 45, 47, 50, 53, 58-60, 70, 83, 94, 105, 108, $109,116,139,152,173,192,194,198$, 209-212, 217, 218, 225-227, 240]. Thereafter, many growth factors were identified in colostrum and milk and partly associated with the growth-promoting or growthinhibitory activity (depending on cell type) of colostrum and milk. At the present time, the growth factors that have been identified in bovine colostrum and milk are the following: EGF [89, 105, 173, 238], BTC [7, 50], IGF-I and/or IGF-II [14, 16, 30, 38, 51, 59, 64, 73, 99, 125, 126, 140, 143, 147, 164, 180, 189, 190, 192, 204, 206, 229, 232], TGF- $\beta 1$ and/or TGF- $\beta 2[14,44,51,64,94$, $151,179,211,212,218,225,227]$, FGF1 and/or FGF2 [83, 104, 178, 189], and PDGF $[14,199,200]$. However, only a few studies have reported concentration values of growth factors in bovine colostrum or cow's milk. A summary of the published concentrations of the growth factors determined in bovine colostrum, milk and whey is reported in Table I. Some cytokines were also quantified in bovine colostrum or milk, but they were not included in Table I since they were not reported in milk extracts enriched in growth factors. These cytokines are: G-CSF [27], IL-1 [102], IL-1 $\beta$ [74], IL-6 and INF- $\gamma[74,102]$, TNF- $\alpha[16,74$, 102, 147] and IL-18 [137].

The concentration of growth factors in milk and colostrum varies widely according to the period of lactation and also to the method used for their quantification. This information has been added in Table I whenever available. It is known that the growth factor concentration in colostrum is the highest during the first hours of calving and generally declines substantially in a time-dependent manner following peak concentration $[7,16,30,38,64,89,105$, $108,109,125,143,147,151,180,190,192$, $198,204,206,210,229,232,240]$. In addition, the total protein concentration decreases markedly during the first four days of lactation $[7,64,93,151,173]$. However, most of the published values of the concentration of growth factors in bovine 
Table I. Concentrations (ng. $\mathrm{mL}^{-1}$ ) of growth factors found in bovine colostrum, milk and whey.

\begin{tabular}{|c|c|c|c|c|c|}
\hline $\begin{array}{l}\text { Growth } \\
\text { factor }\end{array}$ & $\begin{array}{l}\text { Bovine } \\
\text { colostrum }^{1}\end{array}$ & $\begin{array}{l}\text { Bovine } \\
\text { milk }^{1}\end{array}$ & $\begin{array}{l}\text { Bovine } \\
\text { whey } 1\end{array}$ & Methods ${ }^{2}$ & Reference \\
\hline \multirow[t]{3}{*}{ EGF } & & $\sim 2(\mathrm{PM})$ & & RRA & [173] \\
\hline & 324.2 (d 3) & $155.0(\mathrm{PM})$ & $<0.2$ & RRA & [238] \\
\hline & $4-8(12 \mathrm{~h})$ & $<2$ & & RRA & [89] \\
\hline BTC & $2.3(<3 d)$ & 1.9 (> 1 wk) & & RIA & [7] \\
\hline \multirow[t]{21}{*}{ IGF-I } & $\sim 150(\mathrm{~d} 0)$ & $\sim 25$ (d 6) & & RIA & [125] \\
\hline & 200 (d 1) & & & $?$ & [180] \\
\hline & $\sim 147-308(\mathrm{~d} 1)$ & $\sim 35(\mathrm{~d} 56)$ & & RIA & {$[30]$} \\
\hline & & $\sim 30.4$ & & RIA & [164] \\
\hline & $\sim 450$ (d 1) & $\sim 75(\mathrm{~d} 7)$ & & RIA & [143] \\
\hline & & $0.6^{3}(\mathrm{PM})$ & & RIA & [140] \\
\hline & & 4.3 & & $?$ & [99] \\
\hline & 181 (wk 0) & $\sim 5($ wk 1.5) & & RIA & [204] \\
\hline & $2000(\mathrm{~d} 1)$ & & & RRA & [126] \\
\hline & & 4.3 & & RIA & [38] \\
\hline & $190(\mathrm{~d} 0)$ & $5-10(2-7 \mathrm{wk})$ & & RIA & [232] \\
\hline & $\sim 32^{3}$ & $\sim 13^{3}($ wk 4) & & RIA & [190] \\
\hline & $\sim 768(\mathrm{~d} 0)$ & $\sim 7(1 \mathrm{wk})$ & & RIA & [73] \\
\hline & $479(<2 d)$ & & & RIA & [229] \\
\hline & $248-1850(\mathrm{~d} 0)$ & $\begin{array}{c}27-101(\mathrm{~d} 3) \\
13.7(\mathrm{PM})\end{array}$ & & ELISA & [64] \\
\hline & $49-310(0-3 \mathrm{~d})$ & $<2(>14 \mathrm{~d})$ & & $?$ & [16] \\
\hline & $300(\mathrm{~d} 1)$ & $<2(>1 w k)$ & & TR-IMFA & [192] \\
\hline & $870(106 \mathrm{~h})$ & $150(51-80 \mathrm{~h})$ & $190(\mathrm{CW})$ & RIA & {$[51]$} \\
\hline & $103(\mathrm{~d} 2)$ & 4 (wk 4) & & RIA & [147] \\
\hline & $75.5(\mathrm{~d} 0)$ & & & RIA & [206] \\
\hline & 482 & & & $?$ & [175] \\
\hline \multirow[t]{7}{*}{ IGF-II } & $400-600$ (d 0) & $50-100(\mathrm{~d} 6)$ & & RIA & [125] \\
\hline & & $98-107(>60 \mathrm{~d})$ & & $?$ & [99] \\
\hline & 200 (wk 0) & $\sim 2(\mathrm{~d} 1-5 \mathrm{wk})$ & & RIA & [204] \\
\hline & $206(\mathrm{~d} 0)$ & 2-6 (2-7 wk) & & RIA & [232] \\
\hline & & $\sim 6$ (wk 1-49) & & $?$ & [189] \\
\hline & $150(\mathrm{~d} 0)$ & & & $?$ & {$[16]$} \\
\hline & 206 & & & $?$ & [160] \\
\hline \multirow[t]{2}{*}{ TGF- $\beta$} & & $4.3(\mathrm{PM}, \mathrm{AA})$ & 3.7 (AA) & BA & [179] \\
\hline & 100.7 & & & ELISA & {$[160]$} \\
\hline \multirow[t]{2}{*}{ TGF- $\beta 1$} & $12.4-42.6(\mathrm{~d} 0)$ & $0.8-3.5$ (d 3) & & ELISA & {$[64]$} \\
\hline & & 3.7 (PM) & & & \\
\hline TGF- $\beta 2$ & $150-1150(\mathrm{~d} 0)$ & $\begin{array}{c}13-71(\mathrm{~d} \mathrm{3}) \\
38(\mathrm{PM})\end{array}$ & & ELISA & [151] \\
\hline TGF- $\beta 2$ & $300(<10 \mathrm{~h})$ & $66(51-80 \mathrm{~h})$ & $125(\mathrm{CW})$ & ELISA & [51] \\
\hline$\overline{\text { FGF1 }}$ & & & 0.006 & RRA & [178] \\
\hline \multirow{2}{*}{$\overline{\text { FGF2 }}$} & & $0.5-1$ (wk 1-49) & & $?$ & [189] \\
\hline & & & 0.02 & RRA & {$[178]$} \\
\hline
\end{tabular}

${ }^{1}$ When available, stage of lactation (h, hour; d, day; wk, week; mo, month) and other information (AA, acid activated; CW, colostral whey; PM, pasteurized milk) are given.

2 Method used to quantify the growth factor: BA, bioassay; ELISA, enzyme-linked immunosorbent assay;

RIA, radioimmunoassay; RRA, radioreceptor assay; TR-IMFA, time-resolved immuno-fluorescent assay.

3 Values expressed in $\mathrm{ng} \cdot \mathrm{mg}^{-1}$ protein. 
colostrum and milk generally do not take this variable into account.

The most abundant growth factors in bovine milk are EGF $\left(2-155 \mathrm{ng} \cdot \mathrm{mL}^{-1}\right)$, IGF-I (2-101 ng.mL $\left.{ }^{-1}\right)$, IGF-II (2$\left.107 \mathrm{ng} \cdot \mathrm{mL}^{-1}\right)$ and TGF- $\beta 2\left(13-71 \mathrm{ng} \cdot \mathrm{mL}^{-1}\right)$, whereas the concentration of the other growth factors (BTC, TGF- $\beta 1$, FGF1 and FGF2) remains below $4 \mathrm{ng} \cdot \mathrm{mL}^{-1}$. However, the high EGF concentration $\left(155 \mathrm{ng} \cdot \mathrm{mL}^{-1}\right)$ detected in bovine milk, as determined by Yagi et al. [238], was not corroborated by Iacopetta et al. [89], who did not find EGF activity in mature bovine milk and related the high value previously reported to interfering substances in bovine milk. Bastian et al. [7] also suggested that EGF detected in bovine milk might in fact be BTC. For FGF2, it was demonstrated that this growth factor is more concentrated in the cream fraction than in whey isolated from bovine colostrum $[83,104]$. Also, a truncated form of IGF-I, lacking the N-terminal tripeptide Gly-Pro-Glu (-3N:IGF-I), was identified in bovine colostrum $[58,59]$. Shimamato et al. [196] have demonstrated that the truncated form of IGF-I was present in small amounts and that it did not contribute significantly to the proliferative activity of milk.

For comparison purposes, the amounts of the same growth factors measured in human colostrum and milk are reported in Table II. Some other growth factors or cytokines were only quantified in human colostrum or milk, so they were not included in Table II. These components are: TGF- $\alpha[117,145,234]$, G-CSF [26-28, 63], M-CSF [75, 207], TNF- $\alpha[6,39,77,138$, 184, 207], VEGF [202], IL-1 [6, 77, 138, 207], IL-4 and IL-5 [19], IL-6 [6, 17, 19, 77, 183, 186, 207], IL-8 [6, 207], IL-10 [19, 62, 207], IL-12 [24], IL-13 [19], GROS- $\alpha$, RANTES, MCP-1 [207], OPN [141] and IFN- $\gamma[6,17,19,207]$. Except for EGF, which was specifically identified in human milk and found in high amounts (5$\left.140 \mathrm{ng} \cdot \mathrm{mL}^{-1}\right)$, all the other growth factors are at lower concentrations in human milk than in bovine milk. In fact, only EGF and IGF-II were detected in human milk at concentrations higher than $20 \mathrm{ng} \cdot \mathrm{mL}^{-1}$. The difference between human and bovine milk in the amounts of growth factors may reflect the varying needs of the neonate but may also be the consequence of their different protein contents during lactation.

\section{KEY PHYSICOCHEMICAL AND BIOLOGICAL PROPERTIES OF MILK GROWTH FACTORS}

The interest in extracting milk growth factors is related to their numerous physiological functions, which are summarized in Table III for the main growth factors found in bovine colostrum and milk. Although PDGF has been found in milk, it has not been quantified, so it was added to the list since its contribution to the biological activity of milk growth extracts seems important $[13,14]$.

Since the extraction processes developed for the concentration of milk growth factors are either based on their mass, charge or binding affinity, some of their key physicochemical and biological characteristics are listed in Table IV. Except for EGF (pI of 4.8), the isoelectric point values (pI) of the milk growth factors are in the range of 6.5 (IGF-II) to 9.6 (FGF2 and PDGF). These neutral-to-alkaline pI values found for growth factors is one of their most important characteristics with regards to their extraction from colostrum, milk or whey.

The average molecular mass of the active form of milk growth factors (Tab. IV) is between $6000 \mathrm{~g} \cdot \mathrm{mol}^{-1}$ (EGF) and $30000 \mathrm{~g} \cdot \mathrm{mol}^{-1}$ (PDGF). However, when one considers the molecular mass of binding proteins, these values are likely to be much higher.

The molecules of growth factors present in bovine milk are also characterized by their content in disulfide bridges. With the exception of FGF2 that contains no disulfide bridge, all other milk growth factors in their active form contain between 3 (EGF, BTC and IGFs) and 9 (TGF- 32 ) disulfide bridges. The significance of these disulfide bond contents remains unknown but this feature may explain at least partly their relative resistance to heating and extreme $\mathrm{pH}$ values. 
Table II. Concentrations (ng. $\mathrm{mL}^{-1}$ ) of growth factors found in human colostrum and milk.

\begin{tabular}{|c|c|c|c|c|}
\hline Growth factor & $\begin{array}{l}\text { Human } \\
\text { colostrum } 1\end{array}$ & $\begin{array}{c}\text { Human } \\
\text { milk}^{1}\end{array}$ & Method $^{2}$ & Reference \\
\hline \multirow[t]{16}{*}{ EGF } & & 80 & RIA & [208] \\
\hline & & 50 & RIA & [34] \\
\hline & $35-438(<3 d)$ & $20-111(>3 d)$ & RIA & [12] \\
\hline & & 68 (wk 7) & RIA & [135] \\
\hline & $\sim 212(<2 d)$ & $\sim 30$ (wk 2) & RRA & [172] \\
\hline & $2.6-3.5^{3}(\mathrm{~d} 2-4)$ & $3.3-4.3^{3}(\mathrm{~d} 8-10)$ & RRA & [215] \\
\hline & $25-38(\mathrm{~d} 4)$ & $5-12($ wk 4-8) & RIA & [93] \\
\hline & $\sim 332(\mathrm{~d} 1)$ & $\sim 42(\mathrm{~d} 21-41)$ & RRA & [173] \\
\hline & 120 & & RRA & [238] \\
\hline & $\sim 363(\mathrm{~d} 1)$ & $\sim 60(\mathrm{~d} 7)$ & RIA & [41] \\
\hline & & 65 & RIA & [156] \\
\hline & $\sim 73$ (d 3-7) & $\sim 36$ (wk 6-8) & RIA & [42] \\
\hline & & 140 & RRA & [39] \\
\hline & $>200(<2 d)$ & $<50(\mathrm{~d} 7)$ & RIA & [145] \\
\hline & 40-50 (d 0) & $30-40(\mathrm{~d} 8)$ & RRA & [89] \\
\hline & $150.3(\mathrm{~d} 3)$ & $\sim 80(\mathrm{~d} 31-60)$ & RRA & [130] \\
\hline \multirow[t]{7}{*}{$\overline{\text { IGF-I }}$} & $17.6(\mathrm{~d} \mathrm{1})$ & $7.3(\mathrm{~d} 6)$ & RIA & [11] \\
\hline & $>1000$ & & $?$ & [58] \\
\hline & $\sim 10$ (d 3-7) & 19 (wk 6-8) & RIA & [42] \\
\hline & 29-49 (4-92 h) & & $?$ & [214] \\
\hline & $2.2^{3}(<4 \mathrm{~d})$ & $2.9^{3}(8-10 \mathrm{~d})$ & RIA & [140] \\
\hline & & $1.5(3-16 \mathrm{mo})$ & RIA & [48] \\
\hline & $52(<3 d)$ & 3-6 (d 4-8) & RIA & [52] \\
\hline \multirow[t]{2}{*}{$\overline{\text { IGF-II }}$} & & $2.7(3-16 \mathrm{mo})$ & RIA & [48] \\
\hline & $10.5(<3 \mathrm{~d})$ & $35(\mathrm{~d} 7)$ & RIA & [52] \\
\hline TGF- $\beta$ & $1366(<3 d)$ & $953(1 \mathrm{mo})$ & BA & [187] \\
\hline \multirow[t]{6}{*}{$\overline{T \text { TGF- } \beta 1}$} & $3.3(0-5 \mathrm{~d})$ & $0.3(>30 \mathrm{~d})$ & ELISA & [207] \\
\hline & $0.4(\mathrm{~d} 2-6)$ & $0.3-0.5$ (wk 2-12) & ELISA & [77] \\
\hline & $0.14(\mathrm{~d} 0)$ & $0.08(3 \mathrm{mo})$ & ELISA & [101] \\
\hline & $0.3(\mathrm{~d} 3-4)$ & $0.3(1 \mathrm{mo})$ & ELISA & [19] \\
\hline & & $0.6(\mathrm{~d} 35)$ & ELISA & [76] \\
\hline & $0.5(\mathrm{~d} 0-5)$ & & ELISA & [144] \\
\hline \multirow[t]{7}{*}{$\overline{T G F-\beta 2}$} & $0.1(<3 \mathrm{~d})$ & & ELISA & [153] \\
\hline & $1.9(\mathrm{~d} 0-5)$ & $5.3(>30 \mathrm{~d})$ & ELISA & [207] \\
\hline & $3.0(\mathrm{~d} 2-6)$ & $1.9-3.1($ wk 2-12) & ELISA & [77] \\
\hline & $3.3(\mathrm{~d} 0)$ & $1.6(3 \mathrm{mo})$ & ELISA & [101] \\
\hline & $1.1(\mathrm{~d} 3-4)$ & 0.8 (1 mo) & ELISA & [19] \\
\hline & & $1.0(\mathrm{~d} 35)$ & ELISA & [76] \\
\hline & $0.6(\mathrm{~d} 0-5)$ & & ELISA & [144] \\
\hline
\end{tabular}

1 When available, stage of lactation (h, hour; d, day; wk, week; mo, month) are given.

2 Method used to quantify the growth factor: BA, bioassay; ELISA, enzyme-linked immunosorbent assay;

RIA, radioimmunoassay; RRA, radioreceptor assay; TR-IMFA, time-resolved immuno-fluorescent assay.

3 Values expressed in $\mathrm{ng} \cdot \mathrm{mg}^{-1}$ protein. 
Table III. Source, physiological functions and associative behavior of the milk growth factors.

\begin{tabular}{|c|c|c|}
\hline $\begin{array}{l}\text { Growth } \\
\text { factor }\end{array}$ & $\begin{array}{l}\text { Principal } \\
\text { source }\end{array}$ & Primary activity \\
\hline EGF & $\begin{array}{l}\text { Wide range of tissues } \\
\text { and body fluids }\end{array}$ & $\begin{array}{l}\text { Stimulates the proliferation of epidermal, epithelial and embryonic cells } \\
\text { Inhibits the secretion of gastric acid }\end{array}$ \\
\hline BTC & & Promotes wound healing and bone resorption \\
\hline IGF-I & Primarily the liver & Stimulates the proliferation of many cell types \\
\hline IGF-II & Variety of cells & $\begin{array}{l}\text { IGF-I is a stronger mitogen than IGF-II, which stimulates } \\
\text { primarily cells of fetal origin } \\
\text { Influences the differentiation of some cells } \\
\text { Causes hypoglycaemia, improvement of nitrogen balance, lowering } \\
\text { of cholesterol and potassium, and improvement of renal functions }\end{array}$ \\
\hline TGF- $\beta 2$ & $\begin{array}{l}\text { Platelets and many } \\
\text { other cells }\end{array}$ & $\begin{array}{l}\text { Stimulates the growth of cells, especially in connective tissue } \\
\text { Inhibits other cells, such as lymphocytes and epithelial cells } \\
\text { Important role in embryogenesis, wound healing, formation of bone } \\
\text { and cartilage, and control of the immune system }\end{array}$ \\
\hline PDGF & $\begin{array}{l}\text { Platelets and many } \\
\text { other cell types }\end{array}$ & $\begin{array}{l}\text { Plays a role in embryonic development, proliferation of cells of mesenchy- } \\
\text { mal origin, migration, angiogenesis and wound healing }\end{array}$ \\
\hline FGF2 & Wide range of cells & $\begin{array}{l}\text { Important role in proliferation, differentiation and survival } \\
\text { of many cell types } \\
\text { Involved in angiogenesis, wound healing and hematopoiesis }\end{array}$ \\
\hline
\end{tabular}

Table IV. Key physicochemical characteristics of the milk growth factors.

\begin{tabular}{|c|c|c|c|c|c|c|}
\hline $\begin{array}{l}\text { Growth } \\
\text { factor }\end{array}$ & $\begin{array}{l}\text { Amino acid } \\
\text { residues }\end{array}$ & $\begin{array}{l}\text { Molecular mass } \\
\quad\left(\mathrm{g} \cdot \mathrm{mol}^{-1}\right)\end{array}$ & $\mathrm{pI}$ & $\begin{array}{l}\text { Cysteine } \\
\text { residue }\end{array}$ & $\mathrm{S}-\mathrm{S}$ bond ${ }^{1}$ & $\begin{array}{l}\text { Associative } \\
\text { behavior }\end{array}$ \\
\hline EGF & 53 & 6000 & 4.8 & 6 & 3 (IM) & \\
\hline $\mathrm{BTC}^{2}$ & 80 & 22000 & 7.7 & 8 & 3 (IM, 1 P) & \\
\hline IGF-I & 70 & 7650 & 7.8 & 6 & 3 (IM) & Binds to IGFBPs \\
\hline IGF-II & 67 & 7530 & 6.5 & 6 & 3 (IM) & $\begin{array}{l}\text { Binds also to ALS } \\
\text { in serum }\end{array}$ \\
\hline TGF- $\beta 2^{3}$ & $\sim 425$ & $\sim 25000$ & 7.7 & 18 & $\begin{array}{l}8 \text { (IM) } \\
1 \text { (ID) }\end{array}$ & $\begin{array}{l}\text { Associated with LAP } \\
\text { and LTBP } \\
\text { Associated with } \alpha_{2}-\mathrm{M} \\
\text { in serum }\end{array}$ \\
\hline$\overline{\text { PDGF}^{3}}$ & $250-300$ & $\sim 30000$ & 9.6 & 16 & $\begin{array}{l}6 \text { (IM) } \\
2 \text { (ID) }\end{array}$ & $\begin{array}{l}\text { Binds to several plasma } \\
\text { proteins }\left(\alpha_{2}-\mathrm{M}\right) \text { and to } \\
\text { proteins of the ECM }\end{array}$ \\
\hline FGF2 & 146 & 16400 & 9.6 & 4 & 0 & $\begin{array}{c}\text { Interacts with heparin } \\
\text { or heparan sulphate } \\
\text { proteoglycan }\end{array}$ \\
\hline
\end{tabular}

${ }_{1}^{1}$ IM: intramolecular; ID: interdimer; P: potential.

2 Bovine form.

${ }^{3}$ Dimeric active form. 


\subsection{Epidermal growth factor (EGF) and betacellulin (BTC)}

EGF and BTC are members of the EGF family that were detected in milk products in sufficient amount to induce physiological effects. Human EGF is synthesized as a large precursor molecule of 1207 amino acid residues from which the bioactive factor (position 970-1203) is released by proteolytic cleavage. The active form of EGF is a single chain of 53 amino acid residues with a molecular mass of $6 \mathrm{~kg} \cdot \mathrm{mol}^{-1}$. Like the other members of the EGF family, BTC is produced as a longer precursor and the mature BTC (80 amino acids) is released from the cell surface by proteolytic cleavage. The apparent molecular mass of BTC isolated from bovine milk [50] is lower than that of mouse BTC (22 vs. $32 \mathrm{~kg} \cdot \mathrm{mol}^{-1}$ ), probably because it lacks one glycosylation [49]. Both EGF and BTC contain three intramolecular disulfide bonds. However, BTC contains two additional cysteine residues, which probably form a fourth disulfide bridge [193]. The members of the EGF family bind specifically to four EGF receptors (ErbB1 to ErbB4) with tyrosine kinase activity. EGF binds and activates ErbB1 while BTC binds both ErbB1 and ErbB4 [176].

EGF family members stimulate the proliferation of epidermal, epithelial and embryonic cells. They decrease crypt fission in the small intestine or colon during repair but promote crypt hyperplasia [154]. They also act as differentiation factors for some cell types. These growth factors inhibit the secretion of gastric acids $[65,69$, 112] and modulate the synthesis of a number of hormones. They also promote bone resorption and are involved in wound healing processes.

\subsection{Insulin-like growth factor (IGF)}

The insulin-like growth factors are single-chain polypeptides structurally similar to insulin. IGF-I and IGF-II have been identified in most species. Both are composed of $~ 68$ amino acid residues (MW of $\sim 7.6 \mathrm{~kg} \cdot \mathrm{mol}^{-1}$ ) and share about $70 \%$ structural homology with each other. There are two known receptors that specifically recognize the IGFs [97]. The type I IGF receptor is the only receptor to have IGF-mediated signaling functions and most of the actions of both IGFs are mediated by this receptor. At higher concentrations, the insulin receptor can also be stimulated.

IGFs are present in the circulation and throughout the extracellular space almost entirely bound to members of a family of high affinity IGFBPs. Six IGFBPs have been sequenced and cloned and all share structural homology with each other and specifically bind the IGFs, having negligible affinity for insulin [97]. In serum most of the IGF circulates as a $150 \mathrm{~kg} \cdot \mathrm{mol}^{-1}$ complex that consists of IGF-I or IGF-II plus IGFFBP-3 and a non-IGF binding component termed acid labile subunit (ALS) [97]. IGFBP-3 is a $46-53 \mathrm{~kg} \cdot \mathrm{mol}^{-1}$ protein while ALS is a glycoprotein of $88 \mathrm{~kg} \cdot \mathrm{mol}^{-1}$. IGFBP-3 and IGFBP-2 have been identified as the most abundant binding proteins in bovine colostrum and their concentration drastically drops 3 d after parturition [192]. Acid treatment releases the peptide from the binding proteins [11, 203]. The major functions proposed for IGFBPs are: (1) to act as transport proteins in plasma and to control the efflux of IGFs from the vascular space; (2) to prolong the half-lives of the IGFs and regulate their metabolic clearance; (3) to provide a means of tissue- and cell type-specific localization; and (4) to directly modulate interaction of the IGFs with their receptors and thereby indirectly control biological actions [97].

Generally, the in vitro effects of the IGFs are either acute anabolic effects on protein and carbohydrate metabolism, or longerterm effects on cell replication and differentiation of numerous cells. IGFs also present the capacity to inhibit cell death in some cells; for example, in hematopoietic cells. Administration of IGFs to humans causes hypoglycemia [71], improvement in nitrogen balance [37], lowering of cholesterol and potassium [134], and improvement in renal functions [72, 84]. In animals, IGF-I was also shown to have a positive effect on wound healing [213]. Major differences between the effects of insulin and IGF-I in vivo are related to the presence of 
the IGFBPs, which prolong IGF actions and buffer the acute hypoglycemic effects of IGF-I [97].

\subsection{Transforming growth factor-beta (TGF- $\beta$ )}

The transforming growth factors- $\beta$ (TGF- $\beta$ s) family comprises multifunctional growth and differentiation factors that act on most cell types with activities dependent upon the cell type, stage of proliferation and environment [127]. Five isoforms with similar but not identical activities (TGF- $\beta 1$ to $-\beta 5$ ) have been identified and share 66 to $80 \%$ of sequence homology [46]. Three isoforms of TGF- $\beta(-\beta 1,-\beta 2$ and $-\beta 3)$ are known in humans, but TGF- $\beta 2$ is the predominant form in bovine colostrum and milk [44, 94]. The active form is a homodimer with a molecular weight of $\sim 25 \mathrm{~kg} \cdot \mathrm{mol}^{-1}$. Each subunit consists of 112 amino acids, except TGF- $\beta 4$ which has 114 residues [46]. Each polypeptide chain has nine disulfide-bonded cysteines, which are invariant among the five forms. Eight cysteine residues form four intrachain disulfide bonds and one participates in an interchain disulfide bond. The strictly conserved nine cysteine (cysteine knot) in the sequence of the TGF- $\beta$ s suggest an important role in structure and function.

TGF- $\beta$ s are bio-synthesized as longer precursors of $\sim 400$ amino acid residues and released by proteolytic cleavage at the C-terminal end [128]. The biologicallyinactive form is known as latent TGF, which is a complex of TGF- $\beta$ dimer and the $\mathrm{N}$-terminal portion of the precursor (LAP, latency associated peptide) that can also bind to a specific binding protein (LTBP). Rogers et al. [179] have, however, demonstrated that milk-derived TGF- $\beta$ exists predominantly as the small latent complex, lacking the LTBP. The biologicallyactive form of TGF- $\beta$ is obtained by dissociation from the LAP complex. The in vivo activation mechanism is unclear, but it may involve direct cell-to-cell contacts and proteases (primarily plasmin). The in vitro activation methods of latent forms of TGF$\beta$ include acidic or basic $\mathrm{pH}$, heat-treatment and different chaotropic agents. In many
TGF- $\beta$ purification procedures one or more of the listed conditions are used, and the purified TGF- $\beta$ is thus frequently obtained in its active state [185]. In the serum, TGF$\beta$ is associated with $\alpha_{2}$-macroglobulin $\left(\alpha_{2}-\mathrm{M}\right)$. The $\alpha_{2}-\mathrm{M}$ is a homo-tetramer glycoprotein of $718 \mathrm{~kg} \cdot \mathrm{mol}^{-1}$ found in large amounts ( 2 to $4 \mathrm{mg} \cdot \mathrm{mL}^{-1}$ ) in human plasma [123]. The binding of TGF- $\beta$ to $\alpha_{2}-\mathrm{M}$ is reversible and the protein can serve as a reservoir of active TGF- $\beta$ dimers [4].

TGF- $\beta$ effects are mediated by serine/ tyrosine kinase receptors, of which types I and II (T $\beta R I$ and T $\beta$ RII) are the best characterized. T $\beta$ RII binds the ligand but it is incapable of mediating TGF- $\beta$ responses in the absence of the type-I receptor. On the other hand, T $\beta$ RI needs T $\beta$ RII to bind the ligand and both receptors are essential for efficient signal transduction [80]. Two cellsurface proteins (betaglycan and endoglin), known as TGF- $\beta$ receptor type III (T $\beta$ RIII), can also bind TGF- $\beta$ [80]. Individual TGF$\beta$ isotypes bind to the receptors with varying affinities. For example, T $\beta$ RII has a higher affinity for TGF- $\beta 1$ and TGF- $\beta 3$ than for TGF- $\beta 2$ [80].

The physiological function of TGF- $\beta 2$ in milk is unknown but it could be a mediator of mucosal immunity or gut epithelial differentiation in the neonate. TGF- $\beta$ s are recognized to stimulate proliferation of some cells, especially in connective tissue, whereas they act as a growth inhibitor of some other cells, such as lymphocytes and epithelial cells. TGF- $\beta$ s play an important role in embryogenesis, tissue repair, formation of bone and cartilage, and in the control of the immune system.

\subsection{Platelet-derived growth factor (PDGF)}

PDGFs are cationic homo- and heterodimers of disulfide-bound A- and Bpolypeptide chains [79]. Each chain contains eight cysteine residues, two involved in disulfide bonds between the two subunits in the PDGF dimer, and the other six involved in intrachain disulfide bonds. The mature native PDGF is a component of approximately $30 \mathrm{~kg} \cdot \mathrm{mol}^{-1}$. Recently, two additional members of the PDGF family, PDGF-CC 
and PDGF-DD, have been identified [113, 119]. These PDGF family members differ from the others in that they are secreted as an inactive form. PDGFs interact with proteins of the extracellular matrix (ECM), but also with soluble proteins such as $\alpha_{2}-\mathrm{M}$. This latter interaction involves PDGF-BB but not PDGF-AA [18]. Binding of PDGF with proteins modulates the interaction with receptors. Two structurally related protein tyrosine kinase receptors have been described, PDGFR- $\alpha$ and PDGFR- $\beta$. The $\alpha$-receptor binds both A- and B-chains of PDGF with high affinity, whereas the $\beta$ receptor binds only the $\mathrm{B}$-chain with high affinity [79]. PDGF plays an important role during embryogenesis, in particular for the development of the kidneys, blood vessels, lungs, and central nervous system. It has a growth-promoting activity on mesanglial cells, pericytes, alveolar fibroblast, and glial cells. PDGF has been shown to have angiogenic effect and to promote wound healing processes.

\subsection{Fibroblast growth factor 2 (FGF2 or basic FGF)}

At the present time, 22 members of the FGF family have been identified in humans and other vertebrates [148]. Human FGF2 is an $18 \mathrm{~kg} \cdot \mathrm{mol}^{-1}$ protein, but isoforms with higher molecular weight $\left(22-24 \mathrm{~kg} \cdot \mathrm{mol}^{-1}\right)$ have been isolated. However, the reported functions of FGF2 are generally for the $18 \mathrm{~kg} \cdot \mathrm{mol}^{-1}$ isoform [35]. Recent evidence indicates that both low and high molecular weight isoforms can independently activate a biological response in cells through an intracrine pathway, meaning that FGF2 can bind and act at intracellular receptors.

FGF2's signals are mediated by its binding to one of four tyrosine kinase-containing, high-affinity FGF receptors (FGFR1FGFR4). Interaction with heparin or heparan sulfate proteoglycan stabilizes FGF2 and facilitates its binding to the high-affinity transmembrane FGF receptors. This interaction is a prerequisite to the bioactivity of FGF2 $[25,149,220]$. Since milk fat globule membrane containing heparan sulfate proteoglycan is present in milk [197], Hironaka et al. [83] have suggested that
FGF2 in milk might be bound to the heparan sulfate proteoglycan in the milk fat globule membrane.

FGF2 can exert multiple functions on a variety of cells. It plays an important role in proliferation, differentiation and survival of cells of almost all organ systems. Also, it stimulates the growth and development of the new blood vessels (angiogenesis), normal wound healing, tissue development and hematopoiesis [35].

\section{STABILITY OF MILK GROWTH FACTORS}

Growth-promoting activity in human and bovine milk has been found to resist pasteurization [47, 109] and even heattreatments more severe than pasteurization $[60,173]$. The growth-promoting activity of milk is also retained following defatting $[47,109,225-227]$, decaseination $[47,109$, 151, 225-227], treatment with urea and/or guanidine $\mathrm{HCl}$ [107, 198, 226], and disulfide bond reduction by sulfhydryl reducing agents [83, 107, 109].

Jansson et al. [93] showed that EGF in human milk resists pasteurization and that it was recovered in similar amounts following defatting and ultrafiltration of milk samples. However, Yagi et al. [238] have measured a loss of about 50\% in EGF content in pasteurized milk compared with raw milk. In addition, they did not detect EGF in various commercial infant milk formulae.

IGF-I and/or IGF-II also seem to resist pasteurization [48, 51, 64] but IGF-I was not detected in infant milk formulae [140]. Collier et al. [38] also showed that IGF-I is not destroyed by pasteurization, while it was undetectable in commercial infant milk formulae or milk heated to the temperature $\left(121^{\circ} \mathrm{C}\right)$ required for infant formulae preparation.

The activity of a bovine colostrum fraction (BC-1) enriched in TGF- $\beta$ was shown to be sensitive to DTT-treatment [225] and acid-ethanol extraction, but resistant to heat-treatment at $100{ }^{\circ} \mathrm{C}$ for $3 \mathrm{~min}$. The activity of similar fractions (BC-1 and BC-2) was, however, shown to resist reduction 
using 2-mercaptoethanol [226, 227] while the activity of TGF- $\beta 1$ [226] and TGF- $\beta 2$ [227] was affected by 2-mercaptoethanol. However, the BC-1 fraction isolated in 1989 was obtained using a different extraction procedure, which could explain conflicting results reported by the authors. Rogers et al. [179] showed that most (86\%) of the TGF- $\beta$ measured in cow's milk after acid activation $\left(4.3 \mathrm{ng} \cdot \mathrm{mL}^{-1}\right)$ is found in cheese whey $\left(3.7 \mathrm{ng} \cdot \mathrm{mL}^{-1}\right)$. They also showed that acid ( $\mathrm{pH} 2.0)$, alkali ( $\mathrm{pH} 11.0)$, heat (boiled $2 \mathrm{~min})$ and urea $\left(8 \mathrm{~mol} \cdot \mathrm{L}^{-1}\right)$ treatments of TGF- $\beta$ contents in a cationic whey extract increase its activity in a MviLu cell growth inhibition bioassay; the acidic treatment was shown to be the most efficient treatment. Pakkanen [151] and Ginjala and Pakkanen [64] also showed that pasteurized milk contains approximately the same concentration of both TGF- $\beta 1$ and TGF- $\beta 2$ as raw cow's milk. Similar results were obtained by Elfstrand et al. [51] who showed that TGF- $\beta 2$ in a fat-free colostrum fraction resists low pasteurization conditions $\left(60^{\circ} \mathrm{C}, 45 \mathrm{~min}\right)$. However, they also demonstrated a loss of about $30 \%$ in yield of TGF- $\beta 2$ and IGF-I following freezedrying of a UF/DF whey colostrum, suggesting that salts and lactose have a protective effect on these growth factors. Fauquant and Bourtourault (unpublished results) have shown that pasteurization leads to a retention of TGF- $\beta$ in cheese curd and also that curd acidification leads to an increase in this growth factor in the drained whey $(50 \%$ more between $\mathrm{pH} 6.30$ and $\mathrm{pH}$ 4.62), suggesting some interactions with the casein matrix.

FGF was shown to be resistant to DTT [83]. This result is not surprising since this growth factor does not contain a disulfide bond. Also, the interaction between FGF and heparin or heparan sulfate stabilized the molecule against thermal denaturation and proteolysis [56, 136].

\section{BIOAVAILABILITY OF MILK GROWTH FACTORS}

Nutraceutical applications of milk extracts enriched in growth factors imply oral administration of the product, so it may be useful to direct the agent at the intestinal mucosa, where it would have the most potent local effect. Systemic effects may also be expected following the absorption of growth factors and/or binding to their specific intestinal receptors. However, to exert such physiological effects, growth factors have to resist the acidic $\mathrm{pH}$ of the stomach and protease digestion in the gastrointestinal tract. Contradictory results are reported in the literature concerning the stability of growth factors through the gastrointestinal tract. In fact, numerous factors can explain the difference in reported data that are essentially based on the methods used to evaluate digestive stability (purified enzymes, gastric or intestinal content, precipitable material and chromatographic analysis) and/or the bioactivity of growth factors (immunologic, binding receptor and/or growth-promoting properties or other biological activities). Nevertheless, increasing evidence supports the view that orally administrated growth factors would retain their biological activity and exhibit a variety of local and systemic functions.

\subsection{Epidermal growth factor}

Some studies have reported on the in vitro degradation of EGF in the presence of acid and pepsin [3,162], and intestinal digestive enzymes [161, 188]. However, Klagsbrun [107] showed that digestion of human milk samples with a mixture of trypsin and chymotrypsin reduced its growth-stimulating activity in cultured $\mathrm{Balb} / \mathrm{c}$ 3T3 cells to less than $15 \%$. On the other hand, several studies have suggested that EGF is stable in rat or human gastric fluids [21, 22, 156, 169] and degraded to a variable extent in mice, rat or human intestinal fluids [21, 161, 166-169]. However, other studies have shown that EGF is degraded in human gastric fluids $[162,167]$ although it is poorly protected in gastric juice adjusted to higher $\mathrm{pH}[162,167]$. EGF administered orogastrically was shown to be absorbed by the gastrointestinal tract in mice or rats and was detected in numerous tissues [163, 221, 222], mainly in the stomach and intestinal lumen and wall. 
C-terminal truncated forms of EGF have been detected in peptic hydrolysate [162], in human gastric fluids [162], in tryptic and chymotryptic hydrolysates [188], in rat luminal intestinal fluids [169] and in the wall of the rat stomach and/or intestine $[168,169]$. Generally, the C-terminal truncated forms were less active than the intact EGF, but to a variable extent depending on the number of amino acid residues removed $[3,29,67,68,85,162,168,169,188]$. However, N-terminal truncated forms were shown to be ineffective [29].

Whether EGF receptors are present on the apical (luminal) surface in addition to the basolateral membrane of the normal bowel is still controversial [66, 103, 191, 219]. However, several studies suggest that luminal EGF is capable of stimulating growth and repair, acting via the luminal surface, when administered to the damaged bowel of both rats [82, 90-92, 146] and humans [129].

Finally, it was shown that the presence of rat or bovine milk proteins can protect EGF against gastric [167] and intestinal proteolytic degradation [161, 167, 170]. For bovine milk, this effect is maintained after pasteurization [167]. The protective effect of proteins could explain some of the contradictory reported data since fasted or fed subjects were used without discrimination. The presence of protease inhibitors in human milk and bovine milk [33, 114, 120, 121, 233] could also explain this protective effect.

\subsection{Insulin-like growth factor}

IGF-I is degraded in the presence of pepsin, trypsin, chymotrypsin and carboxypeptidase A [195]. However, when incubated in rat or pig gastric fluids, IGF-I remains relatively intact $[157,195,235]$, whereas it is degraded to some extent in luminal intestinal fluids [195]. As observed for EGF, the presence of milk seems to protect IGFs against degradation in the stomach and/or intestine [157, 195, 235].

The N-terminal truncated form of IGF-I (-3N:IGF-I), lacking the tripeptide GlyPro-Glu, was identified in relatively high amounts in bovine colostrum [59] and demonstrated to be highly potent in vivo and in vitro, possibly due to its reduced affinity for several IGFBPs [181].
The presence of both type I and II IGF receptors throughout the gastrointestinal tract has been confirmed in rats and localized to both mucosal and muscularis layers [78], suggesting that exogenous IGFs may be able to interact with the intestine and elicit physiological responses.

Intestinal absorption of IGF-I has been demonstrated in rats $[157,158]$ and pigs [236]. Roffler et al. [177] showed that orallyadministered IGF-I had no effect on the intestinal tract in neonatal calves. However, in calves, rats and piglets, oral ingestion of IGF-I has been shown to provoke various local effects on gastrointestinal tract $[1,2,9$, $10,124,237,241]$, and to increase blood IGF-I concentration [8, 236]. In human athletes, Mero et al. [133] also showed that orally administered IGF-I increased blood IGF-I concentration but the peptide was fragmented $(96 \%)$ when in circulation. Those results thus suggest that dietary IGF-I may be absorbed and cause local and systemic effects.

Finally, Juskevich and Guyer [99] reported on two unpublished toxicity studies of IGF-I. These studies revealed that rats treated by tube feeding with 0.01 to $2 \mathrm{mg} \cdot \mathrm{kg}^{-1}$ of IGF-I per day have no or slight effects on body weight, hematological and urinalysis parameters, and organ weights.

\subsection{Transforming growth factor-beta}

The latent form of TGF- $\beta$ in milk is exposed to low $\mathrm{pH}$ in the stomach, where it is probably activated. The intestine is, therefore, exposed to high concentrations of the active form of TGF- $\beta$. TGF- $\beta 1$ orally administered to TGF- $\beta 1$ null mice is absorbed by the gastrointestinal tract and can be recovered from the neonatal heart, lung and liver, suggesting the possibility of the growth factor acting at sites distant from the gastrointestinal tract [118]. Feeding of IL-10 knockout mice, as a model of IBD, with an enteral diet containing TGF- $\beta 2$ leads to local and systemic effects [150]. Beneficial effects were also observed in children with active intestinal Crohn's disease following oral administration of an enteral diet rich in TGF- $\beta 2$ [55]. Those results thus suggest that TGF- $\beta$ is not only absorbed by the gastrointestinal tract but it can also cause local and systemic effects. 
Table V. Chromatography methods used for the separation of growth factors and IgG from milk, whey or colostrum.

\begin{tabular}{|c|c|c|c|}
\hline $\begin{array}{l}\text { Growth } \\
\text { factor }\end{array}$ & $\begin{array}{l}\text { Raw } \\
\text { material }\end{array}$ & Experimental characteristics & Reference \\
\hline TGF- $\beta 1$ & Platelets & $\begin{array}{l}\text { Gel filtration (Sephadex), weak cation-exchange, } \\
\text { RP-HPLC }\left(\mathrm{C}_{18}\right)\end{array}$ & [230] \\
\hline TGF- $\beta$, PDGF & $\begin{array}{c}\text { Mice neuro- } \\
\text { blastomes }\end{array}$ & $\begin{array}{l}\text { Gel filtration (Sephadex), weak cation-exchange, } \\
\text { RP-HPLC }\left(\mathrm{C}_{18}\right)\end{array}$ & [231] \\
\hline MGF (TGF- $\beta 2)$ & Milk & $\begin{array}{l}\text { Strong cationic resin (Dowex AG50W), low pressure } \\
\text { RP-HPLC (phenyl sepharose), RP-HPLC }\left(\mathrm{C}_{18}\right)\end{array}$ & {$[43,44]$} \\
\hline HBGF & Porcine uterus & Heparin-like resin + butyl sepharose-like resin & [20] \\
\hline TGF- $\beta 1$, TGF- $\beta 2$ & Milk & Idem Cok and Bürk [44] but RP-HPLC $\left(\mathrm{C}_{4}\right)$ & [94] \\
\hline $\mathrm{IgG}$ & Colostrum & $\begin{array}{c}\text { Cation-exchange chromatography, hydroxyapatite } \\
\text { chromatography }\end{array}$ & [165] \\
\hline TGF- $\beta 2$ & Colostrum & $\begin{array}{l}\text { Decaseination, DEAE Sephacell, Sephadex G100, } \\
\text { RP-FPLC }\end{array}$ & [227] \\
\hline IgG & Whey & Separation on Sepharose 6B $\left(\mathrm{CuCl}_{2}\right)$ - binds Cys, $\mathrm{Arg}$, His & [61] \\
\hline $\mathrm{IgG}$ & Whey & $\begin{array}{c}\left.\text { T-gel (-O- } \mathrm{CH}_{2}-\mathrm{CH}_{2}-\mathrm{SO}_{2^{-}} \mathrm{CH}_{2}-\mathrm{CH}_{2}-\mathrm{S}_{-}-\mathrm{CH}_{2}-\mathrm{CH}_{2}-\mathrm{OH}\right) \\
\text { Also binds } \alpha_{2}-\mathrm{M}\end{array}$ & [111] \\
\hline $\mathrm{IgG}$ & Colostrum & $\begin{array}{l}\text { Precipitation of caseins (acidic/rennet), removal of } \\
\beta \text {-lactoglobulin by ion-exchange chromatography }\end{array}$ & [115] \\
\hline $\begin{array}{l}\text { IGF-I, IGF-II } \\
\text { TGF- } \beta, \text { FGF2 }\end{array}$ & Whey & $\begin{array}{l}\text { Separation on Sepharose Fast Flow S + Affinity } \\
\text { chromatography to remove IgG }\end{array}$ & {$[5,60]$} \\
\hline TGF- $\beta 1$, TGF- $\beta 2$ & $\begin{array}{l}\text { Milk and } \\
\text { whey }\end{array}$ & $\begin{array}{c}\text { Separation on S Sepharose + Affinity chromatography } \\
\text { to remove IgG }\end{array}$ & [179] \\
\hline $\begin{array}{l}\text { Milk basic protein } \\
\text { (MBP) }\end{array}$ & Whey & Cationic-exchange (mono S) & [216] \\
\hline TGF- $\beta 2$ & $\begin{array}{l}\text { Bovine } \\
\text { platelets }\end{array}$ & Ethanol-acid extraction from platelets and CM sepharose & [201] \\
\hline TGF- $\beta$, IGF-I & Milk products & Cation exchange resins + hydroxyapatite column & [106] \\
\hline TGF- $\beta 1$, TGF- $\beta 2$ & Bone tissue & $\begin{array}{c}\text { Cation-exchange resins + RP-HPLC, heparin column, } \\
\text { thiophillic resin }\end{array}$ & [98] \\
\hline TGF- $\beta$ & $?$ & Heparin-like resin + butyl sepharose-like resin & [57] \\
\hline
\end{tabular}

\section{APPROACHES TOEXTRACTING MILK GROWTH FACTORS}

The literature on the extraction of milk growth factors as such is not abundant. However, some articles focusing on the concentration of immunoglobulin (IgG) from milk, whey or colostrum are relevant since the methodology used was susceptible to generating growth factor-enriched fractions.

We can group the approaches used for extracting growth factors from milk, whey or colostrum into two main categories; namely, the chromatography-based processes and the membrane separations. Tables V 
Table VI. Membrane separations and other methods used for the separation of growth factors and IgG from milk, whey or colostrum.

\begin{tabular}{|c|c|c|c|}
\hline $\begin{array}{l}\text { Growth } \\
\text { factor }\end{array}$ & $\begin{array}{l}\text { Raw } \\
\text { material }\end{array}$ & Experimental characteristics & Reference \\
\hline IGF-I, IGF-II & Colostrum & $\begin{array}{l}\text { Dilution 1:1 with water } \\
\text { Ultrafiltration and diafiltration at } \mathrm{pH} 8.0\end{array}$ & [86] \\
\hline $\begin{array}{l}\text { IgG, TGF- } \beta 2 \text {, } \\
\text { IGF-I, GH }\end{array}$ & Colostrum & $\begin{array}{c}\text { Microfiltration } 0.8 \mu \mathrm{m} \text { of colostrum decaseination } \\
\text { by rennet }\end{array}$ & {$[51]$} \\
\hline TGF- $\beta 2$ & Whey & $\begin{array}{l}\text { Acidic precipitation followed by heat-treatment } \\
\text { Microfiltration }(0.8 \mu \mathrm{m} \text {, UTP })\end{array}$ & [132] \\
\hline $\begin{array}{l}\text { IgG, TGF- } \beta \text {, } \\
\text { IGF-I }\end{array}$ & Colostrum & $\begin{array}{l}\text { Direct microfiltration }(0.8 \mu \mathrm{m}, \mathrm{UTP}) \text { of diluted colostrum } \\
\left(1: 1 \text { with water, } 0.03 \mathrm{~mol} \cdot \mathrm{L}^{-1} \mathrm{KCl} \text { or } 0.02 \mathrm{~mol} \cdot \mathrm{L}^{-1} \mathrm{NaCl}\right)\end{array}$ & {$[160]$} \\
\hline \multicolumn{4}{|c|}{ OTHER METHODS } \\
\hline $\begin{array}{l}\text { Bombesin type } \\
\text { (EGF, FGF2) }\end{array}$ & $?$ & $75-85 \mathrm{~kg} \cdot \mathrm{mol}^{-1}$ glycoprotein ( 2 mannose $)$ & [182] \\
\hline
\end{tabular}

and VI present a classification of the main approaches published.

\subsection{Chromatography techniques}

Van den Eijnden-Van Raaiji et al. [230, 231] published the earliest papers on the extraction of growth factors from biological material. Their fractionation approach based on cation-exchange chromatography has been used for the extraction of growth factors from bovine platelets [201, 230], mice neuroblastomes [231], bone tissue [98] and porcine uterus [20].

Cation-exchange chromatography (Sepharose) has been used by several authors to extract growth factors from colostrum [227], milk [43, 94, 106] and whey [5, 15, $60,106]$. The main differences between these studies are concerning the downstream purification steps. Tokuyama and Tokuyama [227] and Cox and Burk [43] added a gel filtration step (Sephadex G100) and a RP-FPLC step. Kivits et al. [106] and Quinque et al. [165] used hydroxyapatite filtration in order to remove IGF-I.

As a result, the performances of the various approaches are rather difficult to compare; as, for example, the concentration factors in TGF- $\beta 2$ obtained by the different authors vary from 200X [60], to $10^{5}$ [227] and $10^{6}-10^{7}[43]$. However, despite these important differences in the final degree of purification achieved, it is possible to compare the yield of TGF- $\beta 2$ recovery.

The basic cation-exchange extraction process has been elaborated by Francis et al. [60] and further refined by Rogers et al. [179] and Ballard et al. [5]. Typically, whey is first clarified by microfiltration using a 0.1 - or $0.8-\mu \mathrm{m}$ pore size membrane then the clarified whey is passed through a cationexchange column. The adsorbed material consisting of growth factors, basic proteins ( $\mathrm{LF}$ and LP) and immunoglobulins is eluted at alkaline $\mathrm{pH}$. The eluate is thereafter concentrated by UF/DF and a final sterile filtration is applied before freeze- or spraydrying. The so-called whey growth factors extract (MBWE) contains 5\% of the initial whey proteins but $90 \%$ of its mitogenic activity. Kivits et al. [106] proposed the use of an alkaline eluate ( $\mathrm{pH}$ 7.5-9.5) from the lactoferrin and lactoperoxidase production process to proceed with the extraction of growth factors.

Some attempts to separate $\operatorname{IgG}$ from whey using immobilized metal affinity chromatography [61] or thiophilic resins [111] must also be reported in this review 
since the authors achieved IgG separation together with some lactoferrin, lactoperoxidase and $\alpha_{2}-\mathrm{M}$, a protein able to bind with TGF- $\beta 2$.

Takada et al. [216] have isolated a fraction designated as milk basic protein (MBP) from whey using cation-exchange chromatography. MBP has been found to suppress bone resorption, to promote bone formation [223, 224] and to increase radial bone mineral density in healthy adult women [239]. Further investigations have led the authors to identify firstly cystatin C as responsible for the reduction of bone resorption in vitro by inhibiting the action of cathepsin K [131]. Cystatin C is a $12000 \mathrm{~g} \cdot \mathrm{mol}^{-1}$ cystin protease inhibitor containing 2 disulfide bridges, which had previously been identified in bovine colostrum [81]. Other investigations showed that MBP also contained milk kininogen fragment 1.2 that was responsible for the proliferative effects on osteoblastic MC3T3E1 cells [239]. A third component that has not yet been identified could also be TGF$\beta 2$. Cystatin $C$ and milk kininogen fragment 1.2 are not growth factors as such. However, the authors also mention that the MBP content of basic proteins and growth factors may contribute to the bioactivity of their extract [224].

\subsection{Membrane separations}

Since casein micelles are present in milk and colostrum, the main approach used to separate growth factors from colostrum has been to remove casein by acid or rennet treatment [115] but others [51, 160] have made successful attempts at MF using diluted colostrum.

In the case of whey, Francis et al. [60] clearly demonstrated that ultrafiltration membranes from 3- to $100-\mathrm{g} \cdot \mathrm{mol}^{-1}$ molecular weight cut-off (MWCO) could not successfully concentrate the mitogenic activity of whey. Nevertheless, Hossner and Yemm [86] achieved the separation of IGF-I and IGF-II on a 30 000-mol-1 UF membrane by performing diafiltration (DF) at $\mathrm{pH}$ 8.0, which allowed the passage of IGF-II to the permeate due to its $\mathrm{pI}$ of 7.5.
Maubois et al. [132] proposed a combination of acidification and heat-treatment to precipitate a TGF- $\beta 2$-rich fraction from native whey. This precipitated material was further concentrated using a $0.1-\mu \mathrm{m}$ MF membrane and was characterized by a predominant content in $\alpha$-lactalbumin; it contained $15 \%$ of the initial protein and $70 \%$ of the initial TGF- $\beta 2$.

\subsection{Other methods}

Rozengurt et al. [182] patented a 7500$8500-\mathrm{g} \cdot \mathrm{mol}^{-1}$ (glycopeptide) glycoprotein receptor for bombesin-like growth factors. However, no further refining or application of that method can be found in the literature.

\section{NUTRACEUTICAL APPLICATIONS OF MILK GROWTH FACTOR EXTRACTS}

Several studies have demonstrated the potential of using milk extracts enriched in growth factors as therapeutic compositions for nutraceutical applications. However, overall studies report only on two different milk growth factor extracts. The first extract, named MBWE (mitogenic bovine milk extract), was initially developed by Francis et al. [60] and consists of a mixture of growth factors. The second extract is the oral polymeric diet produced by Nestlé, named CT3211 or Modulen, for which therapeutic effects were essentially attributed to TGF- $\beta 2$.

The extract produced by Nestlé was shown to improve pathological conditions of IL-10 knockout mice, as a model of IBD, supporting the implication of TGF- $\beta 2$ in the observed beneficial effects [150]. This extract was also shown to be an effective oral treatment in children with active Chrohn's disease [54, 55], leading to mucosal healing, together with down-regulation of the pro-inflammatory cytokines IL- $1 \beta$, IL-8 and IFN- $\gamma$. Phylactos et al. [159] have demonstrated that the antiinflammatory action of the extract cannot be related to increased activities of antioxidant metallo-enzymes involved in the disposition of superoxide radicals. However, Lionetti et al. [122] showed that the remission 
observed in children with active Chrohn's disease fed with the extract could be related to its capacity for modifying the gut microflora.

Numerous studies have focused on the milk growth factors (MBWE) developed by Francis et al. [60]. Taylor et al. [218] showed that MBWE is cytoprotective against damage caused by two chemotherapy drugs (eloposide and vinblastine) in cultured intestinal and lung epithelial cells. Horwath et al. [87] reported that orallyadministered MBWE in rats reduced methotrexate-induced damage in the small bowel, suggesting clinical applications for the treatment of intestinal mucositis. Dietary administration of this extract was also shown to reduce intestinal damage in methotrexate-treated rats and to improve gut permeability [228]. MBWE was also shown to be efficient at reducing colonic lipid peroxidation, as evaluated by an ethane breath test in the dextran sulphate sodium (DSS) model of ulcerative colitis in rats.

Wound healing properties were also attributed to MBWE, which was shown to stimulate the skin fibroblast growth and promote the closure of incisional wounds in isolated cultured skin [171]. The efficacy of MBWE was also demonstrated in an animal model of chemotherapy drug-induced oral mucositis [36, 174] that induced both reduced size of ulcers and delayed onset of ulceration [36]. As reported by Smithers [205], clinical trials have demonstrated the safety and acceptability of MBWE administered either as a buccal patch or a mouthwash in normal humans and subjects undergoing high-dose chemotherapy and stem cell transplantation. The safety of MBWE was also shown when administered topically to chronic human leg ulcers at concentrations ranging from 2.5 to $20 \mathrm{mg} \cdot \mathrm{mL}^{-1}$ [205].

Penttila et al. [155] suggested potential application of MBWE to induce oral tolerance in the newborn. In fact, they showed that daily oral administration of MBWE to suckling rats can down-regulate immune activation to a specific orally administered food antigen (ovalbumin). In addition, nonspecific down-regulation in the intestine was observed as assessed by the expression of MHC I.
Finally, MBWE was patented as a therapeutic composition for wound healing [5] and for the treatment of gastrointestinal disorders $[88,95,96]$.

\section{CONCLUSION}

Milk growth factors appear to be a fascinating group of molecules able to constitute, after extraction and purification, new high-added-value markets for the dairy industry. With the development of efficient separation techniques such as chromatography, membrane-related methods or a combination of both, and the increased knowledge of the physicochemical characteristics, most of the identified growth factors can now be extracted and purified from colostrum, milk and its co-products. Further work is, however, needed to further increase the purity of the extracts but, as for many bioactive molecules extracted from biological fluids, the question arises whether extensive fractionation will induce synergistic or detrimental effects on their bioactivity.

The potential of milk growth factors as nutraceuticals is now well documented by in vitro and in vivo data. More clinical data on the physiological effects of milk growth factors are still awaited before they meet wide approval by legal authorities. Such clinical evaluations are likely to present significant challenges given the low concentrations at which milk growth factors are being presumably effective at a human level, and also because of their multifunctionality.

Acknowledgements: The authors wish to thank the Natural Sciences and Engineering Research Council of Canada (NSERC) for their financial support in the Cooperative Research and Development (CRD) Program in partnership with Advitech Inc.

\section{REFERENCES}

[1] Alexander A.N., Carey H.V., Oral IGF-I enhances nutrient and electrolyte absorption in neonatal piglet intestine, Am. J. Physiol. 277 (1999) G619-G625. 
[2] Alexander A.N., Carey H.V., Insulin-like growth factor-I stimulates $\mathrm{Na}^{+}$-dependent glutamine absorption in piglet enterocytes, Dig. Dis. Sci. 47 (2002) 1129-1134.

[3] Araki F., Nakamura H., Nojima N., Tsukumo K., Sakamoto S., Stability of recombinant human epidermal growth factor in various solutions, Chem. Pharm. Bull. (Tokyo) 37 (1989) 404-406.

[4] Arandjelovic S., Freed T.A., Gonias S.L., Growth factor-binding sequence in human alpha2-macroglobulin targets the receptorbinding site in transforming growth factorbeta, Biochemistry 42 (2003) 6121-6127.

[5] Ballard F.J., Francis G.L., Regester G.O., Milk protein mixture for promoting growth of animal cells or treating wounds and a method of making and methods employing the mixture, US Patent 5866 418, 1999.

[6] Basolo F., Conaldi P.G., Fiore L., Calvo S., Toniolo A., Normal breast epithelial cells produce interleukins 6 and 8 together with tumor-necrosis factor: defective IL6 expression in mammary carcinoma, Int. J. Cancer 55 (1993) 926-930.

[7] Bastian S.E., Dunbar A.J., Priebe I.K., Owens P.C., Goddard C., Measurement of betacellulin levels in bovine serum, colostrum and milk, J. Endocrinol. 168 (2001) 203-212.

[8] Baumrucker C.R., Blum J.W., Effects of dietary recombinant human insulin-like growth factor-I on concentrations of hormones and growth factors in the blood of newborn calves, J. Endocrinol. 140 (1994) 15-21.

[9] Baumrucker C.R., Green M.H., Blum J.W., Effects of dietary rhIGF-I in neonatal calves on the appearance of glucose, insulin, Dxylose, globulins and gamma-glutamyl transferase in blood, Domest. Anim. Endocrinol. 11 (1994) 393-403.

[10] Baumrucker C.R., Hadsell D.L., Blum J.W., Effects of dietary insulin-like growth factor I on growth and insulin-like growth factor receptors in neonatal calf intestine, J. Anim. Sci. 72 (1994) 428-433.

[11] Baxter R.C., Zaltsman Z., Turtle J.R., Immunoreactive somatomedin-C/insulin-like growth factor I and its binding protein in human milk, J. Clin. Endocrinol. Metab. 58 (1984) 955-959.

[12] Beardmore J.M., Lewis-Jones D.I., Richards R.C., Urogastrone and lactose concentrations in precolostrum, colostrum, and milk, Pediatr. Res. 17 (1983) 825-828.

[13] Belford D.A., Rogers M.-L., Regester G.O., Francis G.L., Smithers G.W., Liepe I.J.,
Priebe I.K., Ballard F.J., Milk-derived growth factors as serum supplements for the growth of fibroblast and epithelial cells, In Vitro Cell. Dev. Biol. (Animal) 31 (1995) 752-760.

[14] Belford D.A., Rogers M.-L., Francis G.L., Payne C., Ballard F.J., Goddard C., Plateletderived growth factor, insulin-like growth factors, fibroblast growth factors and transforming growth factor $B$ do not account for the cell growth activity present in bovine milk, J. Endocrinol. 154 (1997) 45-55.

[15] Belford D.A., Rogers M.L., Regester G.O., Smithers G.W., Ballard F.J., Francis G.L., Modified milk growth factor, US Patent 6 194208 B1, 2001.

[16] Blum J.W., Hammon H., Colostrum effects on the gastrointestinal tract, and on nutritional, endocrine and metabolic parameters in neonatal calves, Livest. Prod. Sci. 66 (2000) 151-159.

[17] Bocci V., Von Bremen K., Corradeschi F., Franchi F., Luzzi E., Paulesu L., Presence of interferon-gamma and interleukin-6 in colostrum of normal women, Lymphokine Cytokine Res. 12 (1993) 21-24.

[18] Bonner J.C., Osornio-Vargas A.R., Differential binding and regulation of platelet-derived growth factor $\mathrm{A}$ and $\mathrm{B}$ chain isoforms by alpha 2-macroglobulin, J. Biol. Chem. 270 (1995) 16236-16242.

[19] Bottcher M.F., Jenmalm M.C., Garofalo R.P., Bjorksten B., Cytokines in breast milk from allergic and nonallergic mothers, Pediatr. Res. 47 (2000) 157-162.

[20] Brigstock D.R., Heap R.B., Barker P.J., Brown K.D., Purification and characterization of heparin-binding growth factors from porcine uterus, Biochem. J. 266 (1990) 273282.

[21] Britton J.R., George-Nascimento C., Koldovsky O., Luminal hydrolysis of recombinant human epidermal growth factor in the rat gastrointestinal tract: segmental and developmental differences, Life Sci. 43 (1988) 1339-1347.

[22] Britton J.R., George-Nascimento C., Udall J.N., Koldovsky O., Minimal hydrolysis of epidermal growth factor by gastric fluid of preterm infants, Gut 30 (1989) 327-332.

[23] Brown K.D., Blakeley D.M., Cell growthpromoting activity in mammary secretions of the goat, cow and sheep, Br. Vet. J. 139 (1983) 68-78.

[24] Bryan D.L., Hawkes J.S., Gibson R.A., Interleukin-12 in human milk, Pediatr. Res. 45 (1999) 858-859. 
[25] Burgess W.H., Maciag T., The heparin-binding (fibroblast) growth factor family of proteins, Annu. Rev. Biochem. 58 (1989) 575-606.

[26] Calhoun D.A., Christensen R.D., Human developmental biology of granulocyte colonystimulating factor, Clin. Perinatol. 27 (2000) 559-576.

[27] Calhoun D.A., Lunoe M., Du Y., Staba S.L., Christensen R.D., Concentrations of granulocyte colony-stimulating factor in human milk after in vitro simulations of digestion, Pediatr. Res. 46 (1999) 767-771.

[28] Calhoun D.A., Lunoe M., Du Y., Christensen R.D., Granulocyte colony-stimulating factor is present in human milk and its receptor is present in human fetal intestine, Pediatrics 105 (2000) e7.

[29] Calnan D.P., Fagbemi A., Berlanga-Acosta J., Marchbank T., Sizer T., Lakhoo K. Edwards A.D., Playford R.J., Potency and stability of $\mathrm{C}$ terminal truncated human epidermal growth factor, Gut 47 (2000) 622627

[30] Campbell P.G., Baumrucker C.R., Insulinlike growth factor-I and its association with binding proteins in bovine milk, J. Endocrinol. 120 (1989) 21-29.

[31] Capiaumont J., Legrand C., Dousset B., Belleville F., Nabet P., Hybridoma culture in polyether sponge with bovine whey, In Vitro Cell. Dev. Biol. Anim. 31 (1995) 412-414.

[32] Capiaumont J., Ostrovidov S., Legrand C., Belleville F., Nabet P., Bovine whey: a substitute for FBS in CHO-K1 cell cultures, In Vitro Cell. Dev. Biol. Anim. 32 (1996) 8-12.

[33] Carlsson L.C., Westrom B.R., Karlsson B.W., Intestinal absorption of proteins by the neonatal piglet fed on sow's colostrum with either natural or experimentally eliminated trypsin-inhibiting activity, Biol. Neonate 38 (1980) 309-320.

[34] Carpenter G., Epidermal growth factor is a major growth-promoting agent in human milk, Science 210 (1980) 198-199.

[35] Chen C.H., Poucher S.M., Lu J., Henry P.D., Fibroblast growth factor 2: from laboratory evidence to clinical application, Curr. Vasc. Pharmacol. 2 (2004) 33-43.

[36] Clarke J., Butler R., Howarth G., Read L., Regester G., Exposure of oral mucosa to bioactive milk factors reduces severity of chemotherapy-induced mucositis in the hamster, Oral Oncol. 38 (2002) 478-485.

[37] Clemmons D.R., Smith-Banks A., Underwood L.E., Reversal of diet-induced catabolism by infusion of recombinant insulin-like growth
factor-I in humans, J. Clin. Endocrinol. Metab. 75 (1992) 234-238.

[38] Collier R.J., Miller M.A., Hildebrandt J.R., Torkelson A.R., White T.C., Madsen K.S., Vicini J.L., Eppard P.J., Lanza G.M., Factors affecting insulin-like growth factor-I concentration in bovine milk, J. Dairy Sci. 74 (1991) 2905-2911.

[39] Connolly J.M., Rose D.P., Epidermal growth factor-like proteins in breast fluid and human milk, Life Sci. 42 (1988) 1751-1756.

[40] Corps A.N., Brown K.D., Stimulation of intestinal epithelial cell proliferation in culture by growth factors in human and ruminant mammary secretions, J. Endocrinol. 113 (1987) 285-290.

[41] Corps A.N., Blakeley D.M., Carr J., Rees L.H., Brown K.D., Synergistic stimulation of Swiss mouse 3T3 fibroblasts by epidermal growth factor and other factors in human mammary secretions, J. Endocrinol. 112 (1987) 151-159.

[42] Corps A.N., Brown K.D., Rees L.H., Carr J., Prosser C.G., The insulin-like growth factor I content in human milk increases between early and full lactation, J. Clin. Endocrinol. Metab. 67 (1988) 25-29.

[43] Cox D., Bürk R., A polypeptide growth factor from milk, European Patent EP 0313515, 1989.

[44] Cox D.A., Bürk R., Isolation and characterization of milk growth factor, a transforminggrowth-factor-\$2-related polypeptide, from bovine milk, Eur. J. Biochem. 197 (1991) 353-358.

[45] Damerdji O., Derouiche F., Legrand C., Capiaumont J., Bour J.M., Maugras M., Belleville F., Nabet P., Paquet D., Linden G., Utilization of whey fractions as a substitute for fetal calf serum in culture media, Biotechnol. Tech. 2 (1988) 253-258.

[46] Daopin S., Piez K.A., Ogawa Y., Davies D.R., Crystal structure of transforming growth factor-beta 2: an unusual fold for the superfamily, Science 257 (1992) 369-373.

[47] Derouiche A.F., Legrand C., Bour J.M., Capiaumont J., Gelot M.A., Dousset B., Belleville F., Nabet P., Linden G., Biochemical aspects of a whey fraction capable of promoting hybridoma proliferation. Comparison with fetal calf serum, Lait 70 (1990) 313-324.

[48] Donovan S.M., Hintz R.L., Rosenfeld R.G., Insulin-like growth factors I and II and their binding proteins in human milk: effect of heat treatment on IGF and IGF binding protein stability, J. Pediatr. Gastroenterol. Nutr. 13 (1991) 242-253. 
[49] Dunbar A.J., Goddard C., Structure-function and biological role of betacellulin. Int. J. Biochem. Cell Biol. 32 (2000) 805-815.

[50] Dunbar A.J., Priebe I.K., Belford D.A., Goddard C., Identification of betacellulin as a major peptide growth factor in milk: purification, characterization and molecular cloning of bovine betacellulin, Biochem. J. 344 (1999) 713-721.

[51] Elfstrand L., Lindmark-Mansson H., Paulsson M., Nyberg L., Akesson B., Immunoglobulins, growth factors and growth hormone in bovine colostrum and the effect of processing, Int. Dairy J. 12 (2002) 879-887.

[52] Eriksson U., Duc G., Froesch E.R., Zapf J., Insulin-like growth factors (IGF) I and II and IGF binding proteins (IGFBPs) in human colostrum/transitory milk during the first week postpartum: comparison with neonatal and maternal serum, Biochem. Biophys. Res. Commun. 196 (1993) 267-273.

[53] Fassolitis A.C., Novelli R.M., Larkin E.P., Serum substitute in epithelial cell culture media: nonfat dry milk filtrate, Appl. Environ. Microbiol. 42 (1981) 200-203.

[54] Fell J.M., Paintin M., Donnet-Hughes A., Arnaud-Battandier F., MacDonald T.T., Walker-Smith J.A., Remission induced by a new specific oral polymeric diet in children with Crohn's disease, Nestle Nutr. Workshop Ser. Clin. Perform. Programme 2, 1999, pp. 187198.

[55] Fell J.M., Paintin M., Arnaud-Battandier F., Beattie R.M., Hollis A., Kitching P., DonnetHughes A., MacDonald T.T., Walker-Smith J.A., Mucosal healing and a fall in mucosal pro-inflammatory cytokine mRNA induced by a specific oral polymeric diet in paediatric Crohn's disease, Aliment. Pharmacol. Ther. 14 (2000) 281-289.

[56] Flaumenhaft R., Moscatelli D., Rifkin D.B., Heparin and heparan sulfate increase the radius of diffusion and action of basic fibroblast growth factor, J. Cell Biol. 111 (1990) 1651-1659.

[57] Foster B., Germain B., Hammerstone K., Novel TGF- $\beta$ protein purification, US Patent application 20030036629, 2003.

[58] Francis G.L., Read L.C., Ballard F.J., Bagley C.J., Upton F.M., Gravestock P.M., Wallace J.C., Purification and partial sequence analysis of insulin-like growth factor-1 from bovine colostrum, Biochem. J. 233 (1986) 207-213.

[59] Francis G.L., Upton F.M., Ballard F.J., McNeil K.A., Wallace J.C., Insulin-like growth factors 1 and 2 in bovine colostrum, Biochem. J. 251 (1988) 95-103.
[60] Francis G.L., Regester G.O., Webb H.A., Ballard F.J., Extraction from cheese whey by cation-exchange chromatography of factors that stimulate the growth of mammalian cells, J. Dairy Sci. 78 (1995) 1209-1218.

[61] Fukumoto L.R., Li-Chan E., Kwan L., Nakai S., Isolation of immunoglobulin from cheese whey using ultrafiltration and immobilized metal affinity chromatography, Food Res. Int. 27 (1994) 335-348.

[62] Garofalo R., Chheda S., Mei F., Palkowetz K.H., Rudloff H.E., Schmalstieg F.C., Rassin D.K., Goldman A.S., Interleudin-10 in human milk, Pediatr. Res. 37 (1995) 444449.

[63] Gilmore W.S., McKelvey-Martin V.J., Rutherford S., Strain J.J., Loane P., Kell M., Millar S., Human milk contains granulocyte colony stimulating factor, Eur. J. Clin. Nutr. 48 (1994) 222-224.

[64] Ginjala V., Pakkanen R., Determination of transforming growth factor-beta 1 (TGF-beta 1) and insulin-like growth factor (IGF-1) in bovine colostrum samples, J. Immunoassay 19 (1998) 195-207.

[65] Goldenring J.R., Tsunoda Y., Stoch S.A., Coffey R.J., Modlin I.M., Transforming growth factor-alpha (TGF alpha) inhibition of parietal cell secretion: structural requirements for activity, Regul. Pept. 43 (1993) 37-47.

[66] Gonnella P.A., Siminoski K., Murphy R.A., Neutra M.R., Transepithelial transport of epidermal growth factor by absorptive cells of suckling rat ileum, J. Clin. Invest. 80 (1987) 22-32.

[67] Goodlad R.A., Boulton R., Playford R.J., Comparison of the mitogenic activity of human epidermal growth factor I-53 and epidermal growth factor I-48 in vitro and in vivo, Clin. Sci. (Lond.) 91 (1996) 503-507.

[68] Gregory H., Thomas C.E., Young J.A., Willshire I.R., Garner A., The contribution of the C-terminal undecapeptide sequence of urogastrone-epidermal growth factor to its biological action, Regul. Pept. 22 (1988) 217-226.

[69] Guglietta A., Lesch C.A., Effect of h-EGF and h-EGF 1-48 on histamine-stimulated gastric acid secretion in rats and monkeys, J. Physiol. Paris 87 (1993) 343-347.

[70] Guimont C., Marchall E., Girardet J.M., Linden G., Biologically active factors in bovine milk and dairy byproducts: influence on cell culture, Crit. Rev. Food Sci. Nutr. 37 (1997) 393-410. 
[71] Guler H.P., Zapf J., Froesch E.R., Short-term metabolic effects of recombinant human insulin-like growth factor I in healthy adults, N. Engl. J. Med. 317 (1987) 137-140.

[72] Guler H.P., Schmid C., Zapf J., Froesch E.R., Effects of recombinant insulin-like growth factor I on insulin secretion and renal function in normal human subjects, Proc. Natl. Acad. Sci. USA 86 (1989) 2868-2872.

[73] Hadsell D.L., Baumrucker C.R., Kensinger R.S., Effects of elevated blood insulin-like growth factor-I (IGF-I) concentration upon IGF-I in bovine mammary secretions during the colostrum phase, J. Endocrinol. 137 (1993) 223-230.

[74] Hagiwara K., Kataoka S., Yamanaka H., Kirisawa R., Iwai H., Detection of cytokines in bovine colostrum, Vet. Immunol. Immunopathol. 76 (2000) 183-190.

[75] Hara T., Irie K., Saito S., Ichijo M., Yamada M., Yanai N., Miyazaki S., Identification of macrophage colony-stimulating factor in human milk and mammary gland epithelial cells, Pediatr. Res. 37 (1995) 437-443.

[76] Hawkes J.S., Bryan D.L., Gibson R.A., Variations in transforming growth factor beta in human milk are not related to levels in plasma, Cytokine 17 (2002) 182-186.

[77] Hawkes J.S., Bryan D.L., James M.J., Gibson R.A., Cytokines (IL-1beta, IL-6, TNF-alpha, TGF-beta1, and TGF-beta2) and prostaglandin E2 in human milk during the first three months postpartum, Pediatr. Res. 46 (1999) 194-199.

[78] Heinz-Erian P., Kessler U., Funk B., Gais P., Kiess W. Identification and in situ localization of the insulin-like growth factor-II/mannose-6-phosphate (IGF-II/M6P) receptor in the rat gastrointestinal tract: comparison with the IGF-I receptor, Endocrinology 129 (1991) 1769-1778

[79] Heldin C.H., Westermark B., Mechanism of action and in vivo role of platelet-derived growth factor, Physiol. Rev. 79 (1999) 1283 1316.

[80] Hinck A.P., Archer S.J., Qian S.W., Roberts A.B., Sporn M.B., Weatherbee J.A., Tsang M.L., Lucas R., Zhang B.L., Wenker J., Torchia D.A., Transforming growth factor beta 1: three-dimensional structure in solution and comparison with the X-ray structure of transforming growth factor beta 2 , Biochemistry 35 (1996) 8517-8534.

[81] Hirado M., Tsunasawa S., Sakiyama F., Niinobe M., Fujii S., Complete amino acid sequence of bovine colostrum low-Mr cysteine proteinase inhibitor, FEBS Lett. 186 (1985) 41-45.
[82] Hirano M., Iwakiri R., Fujimoto K., Sakata H., Ohyama T., Sakai T., Joh T., Itoh M., Epidermal growth factor enhances repair of rat intestinal mucosa damaged by oral administration of methotrexate, J. Gastroenterol. 30 (1995) 169-176.

[83] Hironaka T., Ohishi H., Masaki T., Identification and partial purification of a basic fibroblast growth factor-like growth factor derived from bovine colostrum, J. Dairy Sci. 80 (1997) 488-495.

[84] Hirschberg R. Brunori G., Kopple J.D, Guler H.P., Effects of insulin-like growth factor I on renal function in normal men, Kidney Int. 43 (1993) 387-397.

[85] Hollenberg M.D., Gregory H., Epidermal growth factor-urogastrone: biological activity and receptor binding of derivatives, Mol. Pharmacol. 17 (1980) 314-320.

[86] Hossner K.L., Yemm R.S., Improved recovery of insulin-like growth factors (IGFs) from bovine colostrum using alkaline diafiltration, Biotechnol. Appl. Biochem. 32 (Pt 3$)$ (2000) 161-166.

[87] Howarth G.S., Francis G.L., Cool J.C., Xu X., Byard R.W., Read L.C., Milk growth factors enriched from cheese whey ameliorate intestinal damage by methotrexate when administered orally to rats, J. Nutr. 126 (1996) 2519-2530.

[88] Huggett A.C., Hugues A., Schiffrin E., Food composition, European Patent EP 0527283, 1993.

[89] Iacopetta B.J., Grieu F., Horisberger M., Sunahara G.I., Epidermal growth factor in human and bovine milk, Acta Paediatr. Scand. 81 (1992) 287-291.

[90] Itoh M., Imai S., Joh T., Kawai T., Katsumi K., Yokochi K., Takeuchi T., Protection of gastric mucosa against ethanol-induced injury by intragastric bolus administration of epidermal growth factor combined with hydroxypropylcellulose, J. Clin. Gastroenterol. 14 (Suppl. 1) (1992) S127-S130.

[91] Itoh M., Imai S., Joh T., Yokoyama Y., Yasue N., Iwai A., Matsusako K., Endoh K., Kawai T., Takeuchi T., Effect of epidermal growth factor in combination with sucralfate or omeprazole on the healing of chronic gastric ulcers in the rat, J. Clin. Gastroenterol. 12 (Suppl. 1) (1990) S187-S191.

[92] Itoh M., Matsuo Y., Gastric ulcer treatment with intravenous human epidermal growth factor: a double-blind controlled clinical study, J. Gastroenterol. Hepatol. 9 (Suppl. 1) (1994) S78-S83. 
[93] Jansson L., Karlson F.A., Westermark B., Mitogenic activity and epidermal growth factor content in human milk, Acta Paediatr. Scand. 74 (1985) 250-253.

[94] Jin Y., Cox D.A., Knecht R., Raschdorf F., Cerletti N., Separation, purification, and sequence identification of TGF-beta 1 and TGF-beta 2 from bovine milk, J. Protein Chem. 10 (1991) 565-575.

[95] Johnson W.S., Playford R.J., Prevention of gastrointestinal damage, PCT WO 98/ $11910 \mathrm{~A} 1,1988$

[96] Johnson W.S., Playford R.J., Prevention of gastrointestinal damage, PCT WO 98/ 11904 A1, 1998.

[97] Jones J.I., Clemmons D.R., Insulin-like growth factors and their binding proteins: biological actions, Endocr. Rev. 16 (1995) 3-34.

[98] Junker L., Lewis M., Nelson R., Isolation of purified TGF- $\beta 1$ and TGF- $\beta 2$ from bone tissue, US Patent 6492 327, 2002.

[99] Juskevich J.C., Guyer C.G., Bovine growth hormone: human food safety evaluation, Science 249 (1990) 875-84.

[100] Juul S.E., Joyce A.E., Zhao Y., Ledbetter D.J., Why is erythropoietin present in human milk? Studies of erythropoietin receptors on enterocytes of human and rat neonates, Pediatr. Res. 46 (1999) 263-268.

[101] Kalliomaki M., Ouwehand A., Arvilommi H., Kero P., Isolauri E., Transforming growth factor-beta in breast milk: a potential regulator of atopic disease at an early age, J. Allergy Clin. Immunol. 104 (1999) 1251-1257.

[102] Kelly G.S., Bovine colostrums: a review of clinical uses, Altern. Med. Rev. 8 (2003) 378-394.

[103] Kelly D., McFadyen M., King T.P., Morgan P.J., Characterization and autoradiographic localization of the epidermal growth factor receptor in the jejunum of neonatal and weaned pigs, Reprod. Fertil. Dev. 4 (1992) 183-191.

[104] Kirihara O., Ohishi H., Functional proteins in bovine milk, Jap. J. Dairy Food Sci. 44 (1995) 9-17.

[105] Kishikawa Y., Watanabe T., Watanabe T., Kubo S., Purification and characterization of cell growth factor in bovine colostrum, J. Vet. Med. Sci. 58 (1996) 47-53.

[106] Kivits M.G.C., Hendricks A.W.J., Malle L.F., Process for obtaining growth factor preparations (TGF- $\beta$ and IGF-I) from milk products having low mutual cross-contamination, PCT WO 01/25276 A1, 2001.
[107] Klagsbrun M., Human milk stimulates DNA synthesis and cellular proliferation in cultured fibroblasts, Proc. Natl. Acad. Sci. USA 75 (1978) 5057-5061.

[108] Klagsbrun M., Bovine colostrum supports the serum-free proliferation of epithelial cells but not of fibroblasts in long-term culture, J. Cell Biol. 84 (1980) 808-814.

[109] Klagsbrun M., Neumann J., The serum-free growth of Balb/c 3T3 cells in medium supplemented with bovine colostrum, J. Supramol. Struct. 11 (1979) 349-359.

[110] Kling P.J., Sullivan T.M., Roberts R.A., Philipps A.E., Koldovsky O., Human milk as a potential enteral source of erythropoietin, Pediatr. Res. 43 (1998) 216-221.

[111] Konecny P., Brown, R.J., Scouten, W.H., Chromatographic purification of immunoglobulin G from bovine milk whey, J. Chromatogr. A 673 (1994) 45-53.

[112] Konturek S.J., Cieszkowski M., Jaworek J., Konturek J., Brzozowski T., Gregory H., Effects of epidermal growth factor on gastrointestinal secretions, Am. J. Physiol. 246 (1984) G580-G586.

[113] LaRochelle W.J., Jeffers M., McDonald W.F., Chillakuru R.A., Giese N.A., Lokker N.A., Sullivan C., Boldog F.L., Yang M., Vernet C., Burgess C.E., Fernandes E., Deegler L.L., Rittman B., Shimkets J., Shimkets R.A., Rothberg J.M., Lichenstein H.S., PDGF-D, a new protease-activated growth factor, Nat. Cell Biol. 3 (2001) 517-521.

[114] Laskowski M. Jr., Laskowski M., Crystalline trypsin inhibitor from colostrum, J. Biol. Chem. 190 (1951) 563-573.

[115] Lefranc-Milot C., Canivez O., Quinque B., Fraction sérocolostrale à forte activité anticorps, utilisation et procédé de fabrication d'une telle fraction, European Patent EP 0722952 A1, 1996.

[116] Legrand C., Capiaumont J., Belleville F., Nabet P., Comparison of metabolism of hybridoma cells cultured in media supplemented with whey or fetal calf serum, Biotechnol. Prog. 9 (1993) 573-579.

[117] Lessaris K.J., Forsythe D.W., Wagner C.L., Effect of human milk fortifier on the immunodetection and molecular mass profile of transforming growth factor-alpha, Biol. Neonate 77 (2000) 156-161.

[118] Letterio J.J., Geiser A.G., Kulkarni A.B., Roche N.S., Sporn M.B., Roberts A.B., Maternal rescue of transforming growth factor-beta 1 null mice, Science 264 (1994) 1936-1938. 
[119] Li X., Ponten A., Aase K., Karlsson L., Abramsson A., Uutela M., Backstrom G., Hellstrom M., Bostrom H., Li H., Soriano P., Betsholtz C., Heldin C.H., Alitalo K., Ostman A., Eriksson U., PDGF-C is a new protease-activated ligand for the PDGF alpha-receptor, Nat. Cell. Biol. 2 (2000) 302-309.

[120] Lindberg T., Protease inhibitors in human milk, Pediatr. Res. 13 (1979) 969-972.

[121] Lindberg T., Ohlsson K., Westrom B., Protease inhibitors and their relation to protease activity in human milk, Pediatr. Res. 16 (1982) 479-483.

[122] Lionetti P., Callegari M.L., Ferrari S., Cavicchi M.C., Pozzi E., de Martino M. Morelli L., Enteral nutrition and microflora in pediatric Crohn's disease, J. Parenter. Enteral Nutr. 29 (2005) S173-S178.

[123] Liu Q., Ling T.Y., Shieh H.S., Johnson F.E., Huang J.S., Huang S.S., Identification of the high affinity binding site in transforming growth factor-beta involved in complex formation with alpha 2-macroglobulin. Implications regarding the molecular mechanisms of complex formation between alpha 2-macroglobulin and growth factors, cytokines, and hormones, J. Biol. Chem. 276 (2001) 46212-46218.

[124] Ma L., Xu R.J., Oral insulinlike growth factor-I stimulates intestinal enzyme maturation in newborn rats, Life Sci. 61 (1997) 51-58.

[125] Malven P.V., Head H.H., Collier R.J., Buonomo F.C., Periparturient changes in secretion and mammary uptake of insulin and in concentrations of insulin and insulinlike growth factors in milk of dairy cows, J. Dairy Sci. 70 (1987) 2254-2265.

[126] Marcotty C., Frankenne F., Van Beeumen J., Maghuin-Rogister G., Hennen G., Insulin-like growth factor I (IGF-I) from cow colostrum: purification and characterization, Growth Regul. 1 (1991) 56-61.

[127] Massague J., The transforming growth factor-beta family, Annu. Rev. Cell Biol. 6 (1990) 597-641.

[128] Massague J., TGF-beta signal transduction, Annu. Rev. Biochem. 67 (1998) 753-791.

[129] Matsuo Y., Gotoh Y., Itoh M., Asaki S., Sugiyama M., Ohshiba S., Nagataki S., Hayakawa A., Ogawa N., Urakawa M., Yamazaki Y., Randomized, double blind comparison of epidermal growth factor from human urine (MG111) with the active placebo in treatment of gastric ulcer, Hellenic J. Gastroenterol. 5 (1992) 217.
[130] Matsuoka Y.,Idota T., The concentration of epidermal growth factor in Japanese mother's milk, J. Nutr. Sci. Vitaminol. 41 (1995) 241-251.

[131] Matsuoka Y., Serizawa A., Yoshioka T., Yamamura J., Morita Y., Kawakami H., Toba Y., Takada Y., Kumegawa M., Cystatin $\mathrm{C}$ in milk basic protein (MBP) and its inhibitory effect on bone resorption in vitro, Biosci. Biotechnol. Biochem. 66 (2002) 2531-2536.

[132] Maubois J.L., Fauquant J., Jouan P., Bourtourault M., Method for obtaining a TGF-beta enriched protein fraction in activated form, protein fraction and therapeutic applications, PCT/WO 03/006500, 2003.

[133] Mero A., Kahkonen J., Nykanen T., Parviainen T., Jokinen I., Takala T., Nikula T., Rasi S., Leppaluoto J., IGF-I, IgA, and IgG responses to bovine colostrum supplementation during training, J. Appl. Physiol. 93 (2002) 732-739.

[134] Miell J.P., Taylor A.M., Jones J., Buchanan C.R., Rennie J., Sherwood R., Leicester R., Ross R.J., Administration of human recombinant insulin-like growth factor-I to patients following major gastrointestinal surgery, Clin. Endocrinol. (Oxf.) 37 (1992) 542-551.

[135] Moran J.R., Courtney M.E., Orth D.N., Vaughan R., Coy S., Mount C.D., Sherrell B.J., Greene H.L., Epidermal growth factor in human milk: daily production and diurnal variation during early lactation in mothers delivering at term and at premature gestation, J. Pediatr. Gastroent. Nutr. 103 (1983) 402-405.

[136] Moscatelli D., High and low affinity binding sites for basic fibroblast growth factor on cultured cells: absence of a role for low affinity binding in the stimulation of plasminogen activator production by bovine capillary endothelial cells, J. Cell Physiol. 131 (1987) 123-130.

[137] Muneta Y., Yoshihara K., Minagawa Y., Nagata R., Yasuyuki M., Yamaguchi T., Takehara K., Bovine IL-18 ELISA: detection of IL-18 in sera of pregnant cow and newborn calf, and in colostrum, J. Immunoassay Immunochem. 26 (2005) 203-213.

[138] Munoz C., Endres S., van der Meer J., Schlesinger L., Arevalo M., Dinarello C., Interleukin-1 beta in human colostrum, Res. Immunol. 141 (1990) 505-513.

[139] Nabet P., Belleville-Nabet F., Linden G., Les peptides du lait à activité physiologique I. Facteurs de croissance dans le lait et le lactosérum, Lait 71 (1991) 225-239. 
[140] Nagashima K., Itoh K., Kuroume T., Levels of insulin-like growth factor I in full- and preterm human milk in comparison to levels in cow's milk and in milk formulas, Biol. Neonate 58 (1990) 343-346.

[141] Nagatomo T., Ohga S., Takada H., Nomura A., Hikino S., Imura M., Ohshima K., Hara T., Microarray analysis of human milk cells: persistent high expression of osteopontin during the lactation period, Clin. Exp. Immunol. 138 (2004) 47-53.

[142] Noda K., Umeda M., Ono T., Transforming growth factor activity in human colostrum, Jap. J. Cancer Res. 75 (1984) 109-112.

[143] Oda S., Satoh H., Sugawara T., Matsunaga N., Kuhara T., Katoh K., Shoji Y., Nihei A., Ohta M., Sasaki Y., Insulin-like growth factor-I, GH, insulin and glucagon concentrations in bovine colostrum and in plasma of dairy cows and neonatal calves around parturition, Comp. Biochem. Physiol. A 94 (1989) 805-808.

[144] Ogawa J., Sasahara A., Yoshida T., Sira M.M., Futatani T., Kanegane H., Miyawaki $\mathrm{T}$., Role of transforming growth factor-beta in breast milk for initiation of IgA production in newborn infants, Early Hum. Dev. 77 (2004) 67-75.

[145] Okada M., Ohmura E., Kamiya Y., Murakami H., Onoda N., Iwashita M., Wakai K., Tsushima T., Shizume K., Transforming growth factor (TGF)-alpha in human milk, Life Sci. 48 (1991) 1151-1156.

[146] Olsen P.S., Poulsen S.S., Therkelsen K., Nexo E., Effect of sialoadenectomy and synthetic human urogastrone on healing of chronic gastric ulcers in rats, Gut 27 (1986) 1443-1449.

[147] Ontsouka C.E., Bruckmaier R.M., Blum J.W., Fractionized milk composition during removal of colostrum and mature milk, J. Dairy Sci. 86 (2003) 2005-2011.

[148] Ornitz D.M., Itoh N., Fibroblast growth factors, Genome Biol. 2 (2001) 1-12.

[149] Ornitz D.M., Yayon A., Flanagan J.G., Svahn C.M., Levi E., Leder P., Heparin is required for cell-free binding of basic fibroblast growth factor to a soluble receptor and for mitogenesis in whole cells, Mol. Cell Biol. 12 (1992) 240-247.

[150] Oz H.S., Ray M., Chen T.S., McClain C.J., Efficacy of a transforming growth factor beta 2 containing nutritional support formula in a murine model of inflammatory bowel disease, J. Am. Coll. Nutr. 23 (2004) 220-226.
[151] Pakkanen R., Determination of transforming growth factor-beta 2 (TGF-beta 2) in bovine colostrum samples, J. Immunoassay 19 (1998) 23-37.

[152] Pakkanen R., Kanttinen A., Satama L., Aalto J., Bovine colostrum fraction as a serum substitute for the cultivation of mouse hybridomas, Appl. Microbiol. Biotechnol. 37 (1992) 451-456.

[153] Palkowetz K.H., Royer C.L., Garofalo R., Rudloff H.E., Schmalstieg F.C. Jr., Goldman A.S., Production of interleukin-6 and interleukin- 8 by human mammary gland epithelial cells, J. Reprod. Immunol. 26 (1994) 57-64.

[154] Park H.S., Goodlad R.A., Ahnen D.J., Winnett A., Sasieni P., Lee C.Y., Wright N.A., Effects of epidermal growth factor and dimethylhydrazine on crypt size, cell proliferation, and crypt fission in the rat colon. Cell proliferation and crypt fission are controlled independently, Am. J. Pathol. 151 (1997) 843-852.

[155] Penttila I.A., Zhang M.F., Bates E., Regester G., Read L.C., Zola H., Immune modulation in suckling rat pups by a growth factor extract derived from milk whey, J. Dairy Res. 68 (2001) 587-599.

[156] Pesonen K., Viinikka L., Koskimies A., Banks A.R., Nicolson M., Perheentupa J., Size heterogeneity of epidermal growth factor in human body fluids, Life Sci. 40 (1987) 2489-2494.

[157] Philipps A.F., Rao R., Anderson G.G., McCracken D.M., Lake M., Koldovsky O., Fate of insulin-like growth factors I and II administered orogastrically to suckling rats, Pediatr. Res. 37 (1995) 586-592.

[158] Philipps A.F., Kling P.J., Grille J.G., Dvorak $B$. Intestinal transport of insulin-like growth factor-I (IGF-I) in the suckling rat, J. Pediatr. Gastroenterol. Nutr. 35 (2002) 539-544.

[159] Phylactos A.C., Fasoula I.N., ArnaudBattandier F., Walker-Smith J.A., Fell J.M., Effect of enteral nutrition on antioxidant enzyme systems and inflammation in paediatric Crohn's disease, Acta Paediatr. 90 (2001) 883-888.

[160] Piot M., Fauquant J., Madec M.-N., Maubois J.-L., Preparation of serocolostrum by membrane filtration, Lait 84 (2004) 333-341.

[161] Playford R.J., Woodman A.C., Clark P., Watanapa P., Vesey D., Deprez P.H., Williamson R.C., Calam J., Effect of luminal growth factor preservation on intestinal growth, Lancet 341 (1993) 843-848. 
[162] Playford R.J., Marchbank T., Calnan D.P., Calam J., Royston P., Batten J.J., Hansen H.F., Epidermal growth factor is digested to smaller, less active forms in acidic gastric juice, Gastroenterology 108 (1995) 92-101.

[163] Popliker M., Shatz A., Avivi A., Ullrich A., Schlessinger J., Webb C.G., Onset of endogenous synthesis of epidermal growth factor in neonatal mice, Dev. Biol. 119 (1987) $38-44$.

[164] Prosser C.G., Fleet I.R., Corps A.N., Increased secretion of insulin-like growth factor I into milk of cows treated with recombinantly derived bovine growth hormone, J. Dairy Res. 56 (1989) 17-26.

[165] Quinque B., Lesur H., Spick G., Montreuil J., Thomas D., Method for treating colostrum by hydroxyapatite adsorption chromatography, an active fraction of colostrum obtained, and a cellular medium containing the same, PCT WO 92/00014 A1, 1992.

[166] Rao R.K., Luminal processing of epidermal growth factor in mouse gastrointestinal tract in vivo, Peptides 16 (1995) 505-513.

[167] Rao R.K., Baker R.D., Baker S.S., Bovine milk inhibits proteolytic degradation of epidermal growth factor in human gastric and duodenal lumen, Peptides 19 (1998) 495504.

[168] Rao R.K., Koldovsky O., Korc M., Pollack P.F., Wright S., Davis T.P., Processing and transfer of epidermal growth factor in developing rat jejunum and ileum, Peptides 11 (1990) 1093-1102.

[169] Rao R.K., Koldovsky O., Grimes J., Williams C., Davis T.P., Regional differences in gastrointestinal processing and absorption of epidermal growth factor in suckling rats, Am. J. Physiol. 261 (1991) G790-G798.

[170] Rao R.K., Lam K., Philipps A.F., Williams C., Lake M., Koldovsky O., Presence of multiple forms of peptidase inhibitors in rat milk, J. Pediatr. Gastroenterol. Nutr. 17 (1993) 414-420.

[171] Rayner T.E., Cowin A.J., Robertson J.G., Cooter R.D., Harries R.C., Regester G.O., Smithers G.W., Goddard C., Belford D.A., Mitogenic whey extract stimulates wound repair activity in vitro and promotes healing of rat incisional wounds, Am. J. Physiol. Regul. Integr. Comp. Physiol. 278 (2000) R1651-R1660.

[172] Read L.C., Upton F.M., Francis G.L., Wallace J.C., Dahlenberg G.W., Ballard F.J., Changes in the growth-promoting activity of human milk during lactation, Pediatr. Res. 18 (1984) 133-139.
[173] Read L.C., Francis G.L., Wallace J.C., Ballard F.J., Growth factor concentrations and growth-promoting activity in human milk following premature birth, J. Dev. Physiol. 7 (1985) 135-145.

[174] Regester G.O., Belford D.A., West R.J., Goddard C., Development of minor dairy components as therapeutic agents - whey growth factor extract, a case study, Aust. J. Dairy Technol. 58 (2003) 104-106.

[175] Rehberger B., Gallmann P., Blum J., Optimized isolation procedure of a crude insulinlike growth factor concentrate, in: Desalination for the 10th Aachener Membran Kolloquium, March 16-17th, Aachen, Germany, 2005, available at http:// www.alp.admin.ch/de/publikationen/docs/ pub_RehbergerB_2005_15726.pdf.

[176] Riese D.J. 2nd, Stern D.F., Specificity within the EGF family/ErbB receptor family signaling network, Bioassays 20 (1998) 41-48.

[177] Roffler B., Fah A., Sauter S.N., Hammon H.M., Gallmann P., Brem G., Blum J.W., Intestinal morphology, epithelial cell proliferation, and absorptive capacity in neonatal calves fed milk-born insulin-like growth factor-I or a colostrum extract, J. Dairy Sci. 86 (2003) 1797-1806

[178] Rogers M.-L., Belford D.A., Francis G.L., Ballard F.J., Identification of fibroblast growth factors in bovine cheese whey, J. Dairy Res. 62 (1995) 501-507.

[179] Rogers M.-L., Goddard C., Regester G.O., Ballard F.J., Belford D.A., Transforming growth factor $\beta$ in bovine milk: concentration stability and molecular mass forms, J. Endocrinol. 151 (1996) 77-86.

[180] Ronge H., Blum J.W., Somatomecin C and other hormones in dairy cows around parturition in newborn calves and in milk, J. Anim. Physiol. Anim. Nutr. 60 (1988) 168176.

[181] Ross M., Francis G.L., Szabo L., Wallace J.C., Ballard F.J., Insulin-like growth factor (IGF)-binding proteins inhibit the biological activities of IGF-1 and IGF-2 but not des(1-3)-IGF-1, Biochem. J. 258 (1989) 267-272.

[182] Rozengurt E., Woll P., Zachary I., Growth factor receptors, US Patent 5441935, 1992.

[183] Rudloff H.E., Schmalstieg F.C. Jr., Palkowetz K.H., Paszkiewicz E.J., Goldman A.S., Interleukin-6 in human milk, J. Reprod. Immunol. 23 (1993) 13-20.

[184] Rudloff H.E., Schmalstieg F.C., Mushtaha A.A., Palkowetz K.H., Liu S.K., Goldman 
A.S., Tumor necrosis factor- $\alpha$ in human milk, Pediatr. Res. 31 (1992) 29-33.

[185] Saharinen J., Hyytiainen M., Taipale J., Keski-Oja J., Latent transforming growth factor-beta binding proteins (LTBPs) structural extracellular matrix proteins for targeting TGF-beta action, Cytokine Growth Factor Rev. 10 (1999) 99-117.

[186] Saito S., Maruyama M., Kato Y., Moriyama I., Ichijo M., Detection of IL-6 in human milk and its involvement in IgA production, J. Reprod. Immunol. 20 (1991) 267-276.

[187] Saito S., Yoshida M., Ichijo M., Ishizaka S., Tsujii T., Transforming growth factor-beta (TGF- $\beta$ ) in human milk, Clin. Exp. Immunol. 94 (1993) 220-224

[188] Savage C.R. Jr., Inagami T., Cohen S., The primary structure of epidermal growth factor, J. Biol. Chem. 247 (1972) 7612-7621.

[189] Schams D., Growth factors in milk, Endocr. Regul. 28 (1994) 3-8.

[190] Schams D., Einspanier R., Growth hormone, IGF-I and insulin in mammary gland secretion before and after parturition and possibility of their transfer into the calf, Endocr. Regul. 25 (1991) 139-143.

[191] Scheving L.A., Shiurba R.A., Nguyen T.D., Gray G.M., Epidermal growth factor receptor of the intestinal enterocyte. Localization to laterobasal but not brush border membrane, J. Biol. Chem. 264 (1989) 1735-1741.

[192] Sejrsen K., Pedersen L.O., Vestergaard M., Purup S., Biological activity of bovine milk. Contribution of IGF-I and IGF binding proteins, Livest. Prod. Sci. 70 (2001) 79-85.

[193] Seno M., Tada H., Kosaka M., Sasada R., Igarashi K., Shing Y., Folkman J., Ueda M., Yamada H., Human betacellulin, a member of the EGF family dominantly expressed in pancreas and small intestine, is fully active in a monomeric form, Growth Factors 13 (1996) 181-191.

[194] Sereni A., Baserga R., Routine growth of cell lines in medium supplemented with milk instead of serum, Cell Biol. Int. Rep. 5 (1981) 339-345.

[195] Shen W.H., Xu R.J., Stability of insulinlike growth factor I in the gastrointestinal lumen in neonatal pigs, J. Pediatr. Gastroenterol. Nutr. 30 (2000) 299-304.

[196] Shimamoto G.T., Byatt J.C., Jennings M.G., Comens-Keller P.G., Collier R.J., Destripeptide insulin-like growth factor-I in milk from bovine somatotropin-treated cows, Pediatr. Res. 32 (1992) 296-300.
[197] Shimizu M., Uryu N., Yamauchi K., Presence of heparan sulfate in the fat globule membrane of bovine and human milk, Agric. Biol. Chem. 45 (1981) 741.

[198] Shing Y.W., Klagsbrun M., Human and bovine milk contain different set of growth factors, Endocrinology 115 (1984) 273-282.

[199] Shing Y., Davidson S., Klagsbrun M., Purification of polypeptide growth factors from milk, Methods Enzymol. 146 (1987) 4248.

[200] Shing Y., Klagsbrun M., Purification and characterization of a bovine colostrumderived growth factor, Mol. Endocrinol. 1 (1987) 335-338.

[201] Si X.H., Yang L.J., Extraction and purification of TGFbeta and its effect on the induction of apoptosis of hepatocytes, World J. Gastroenterol. 7 (2001) 527-531.

[202] Siafakas C.G., Anatolitou F., Fusunyan R.D., Walker W.A., Sanderson I.R., Vascular endothelial growth factor (VEGF) is present in human breast milk and its receptor is present on intestinal epithelial cells, Pediatr. Res. 45 (1999) 652-657.

[203] Simmen F.A., Simmen R.C., Reinhart G., Maternal and neonatal somatomedin C/insulin-like growth factor-I (IGF-I) and IGF binding proteins during early lactation in the pig, Dev. Biol. 130 (1988) 16-27.

[204] Skaar T.C., Vega J.R., Pyke S.N., Baumrucker C.R., Changes in insulin-like growth factor-binding proteins in bovine mammary secretions associated with pregnancy and parturition, J. Endocrinol. 131 (1991) 127-133.

[205] Smithers G.W., Isolation of growth factors from whey and their application in food and biotechnology industries - a brief review, Bull. Int. Dairy Fed. 389 (2004) 16-19.

[206] Sparks A.L., Kirkpatrick J.G., Chamberlain C.S., Waldner D., Spicer L.J., Insulin-like growth factor-I and its binding proteins in colostrum compared to measures in serum of Holstein neonates, J. Dairy Sci. 86 (2003) 2022-2029.

[207] Srivastava M.D., Srivastava A., Brouhard B., Saneto R., Groh-Wargo S., Kubit J., Cytokines in human milk, Res. Commun. Mol. Pathol. Pharmacol. 93 (1996) 263-287.

[208] Starkey R.H., Orth D.N., Radioimmunoassay of human epidermal growth factor (urogastrone), J. Clin. Endocrinol. Metab. 45 (1977) 1144-1153.

[209] Steimer K.S., Klagsbrun M., Serum-free growth of normal and transformed fibroblasts in milk: differential requirements for fibronectin, J. Cell Biol. 88 (1981) 294-300. 
[210] Steimer K.S., Packard R., Holden D., Klagsbrun M., The serum-free growth of cultured cells in bovine colostrum and in milk obtained later in the lactation period, J. Cell. Physiol. 109 (1981) 223-234.

[211] Stoeck M., Ruegg C., Miescher S., Carrel S., Cox D., Von Fliedner V., Alkan S., Comparison of the immunosuppressive properties of milk growth factor and transforming growth factors beta 1 and beta 2, J. Immunol. Methods 143 (1989) 3258-3265.

[212] Stoeck M., Sommermeyer H., Miescher S. Cox D., Alkan S., Szamel M., Transforming growth factors beta 1 and beta 2 as well as milk growth factor decrease anti-CD3induced proliferation of human lymphocytes without inhibiting the anti-CD3-mediated increase of $\left[\mathrm{Ca}^{2+}\right] \mathrm{i}$ and the activation of protein kinase C, FEBS Lett. 249 (1989) 289-292.

[213] Suh D.Y., Hunt T.K., Spencer E.M., Insulin-like growth factor-I reverses the impairment of wound healing induced by corticosteroids in rats, Endocrinol. 131 (1992) 2399-2403.

[214] Suikkari A.M., Insulin-like growth factor (IGF-I) and its low molecular weight binding protein in human milk, Eur. J. Obstet. Gynecol. Reprod. Biol. 30 (1989) 19-25.

[215] Suzuki S., Yagi H., Kuroume T., Epidermal growth factor in human milk, J. Pediatr. 104 (1984) 962.

[216] Takada Y., Kobayashi N., Matsuyama H., Kato K., Yamamura J., Yahiro M., Kumegawa M., Aoe S., Whey protein suppresses the osteoclast-mediated bone resorption and osteoclast cell formation, Int. Dairy J. 7 (1997) 821-825.

[217] Tapper D., Klagsbrun M., Neumann J., The identification and clinical implications of human breast milk mitogen, J. Pediatr. Surg. 14 (1979) 803-808.

[218] Taylor V.L., Goddard C., Read L.C., A milk growth factor extract reduces chemotherapeutic drug toxicity in epithelial cells in vitro, In Vitro Cell. Dev. Biol. Anim. 37 (2001) 310-318

[219] Thompson J.F., Specific receptors for epidermal growth factor in rat intestinal microvillus membranes, Am. J. Physiol. 254 (1988) G429-G435.

[220] Thompson L.D., Pantoliano M.W., Springer B.A., Energetic characterization of the basic fibroblast growth factor-heparin interaction: identification of the heparin binding domain, Biochemistry 33 (1994) 3831-3840.
[221] Thornburg W., Matrisian L., Magun B., Koldovsky O., Gastrointestinal absorption of epidermal growth factor in suckling rats, Am. J. Physiol. 246 (1984) G80-G85.

[222] Thornburg W., Rao R.K., Matrisian L.M., Magun B.E., Koldovsky O., Effect of maturation on gastrointestinal absorption of epidermal growth factor in rats, Am. J. Physiol. 253 (1987) G68-G71.

[223] Toba Y., Takada Y., Yamamura J., Tanaka M., Matsuoka Y., Kawakami H., Itabashi A., Aoe S., Kumegawa M., Milk basic protein: a novel protective function of milk against osteoporosis, Bone 27 (2000) 403-408.

[224] Toba Y., Takada Y., Matsuoka Y., Morita Y., Motouri M., Hirai T., Suguri T., Aoe S., Kawakami H., Kumegawa M., Takeuchi A., Itabashi A., Milk basic protein promotes bone formation and suppresses bone resorption in healthy adult men, Biosci. Biotechnol. Biochem. 65 (2001) 1353-1357.

[225] Tokuyama H., Tokuyama Y., Bovine colostric transforming growth factor-betalike peptide that induces growth inhibition and changes in morphology of human osteogenic sarcoma cells (MG-63), Cell Biol. Int. Rep. 13 (1989) 251-258.

[226] Tokuyama H., Tokuyama Y., Migita S., Isolation of two new proteins from bovine colostrum which stimulate epidermal growth factor-dependent colony formation of NRK-49F cells, Growth Factors 3 (1990) 105-114.

[227] Tokuyama Y., Tokuyama H., Purification and identification of TGF-B2-related growth factor from bovine colostrum, J. Dairy Res. 60 (1993) 99-109.

[228] Tran C.D., Howarth G.S., Coyle P., Philcox J.C., Rofe A.M., Butler R.N., Dietary supplementation with zinc and a growth factor extract derived from bovine cheese whey improves methotrexate-damaged rat intestine, Am. J. Clin. Nutr. 77 (2003) 1296-1303.

[229] Vacher P.Y., Blum J.W., Age dependency of insulin like growth factor 1, insulin protein and immunoglobulin concentrations and gamma glutamyl transferase activity in first colostrum of dairy cows, Milchwissenschaft 48 (1993) 423-425.

[230] Van den Eijnden-Van Raaij A.J., Koornneef I., Van Zoelen E.J., A new method for high yield purification of type beta transforming growth factor from human platelet, Biochem. Biophys. Res. Comm. 157 (1988) $16-23$.

[231] Van den Eijnden-Van Raaij A.J., Koornneef I., Van Oostwaard T.M., Feyen A., Kruijer W., De Laat S.W., Van Zoelen E.J., Purification 
of a growth factor related to platelet-derived growth factor and a type beta transforming growth factor secreted by mouse neuroblastoma cells. A general strategy for the purification of basic polypeptide growth factors, Biochem. J. 257 (1989) 375-382.

[232] Vega J.R., Gibson C.A., Skaar T.C., Hadsell D.L., Baumrucker C.R., Insulin-like growth factor (IGF)-I and -II and IGF binding proteins in serum and mammary secretions during the dry period and early lactation in dairy cows, J. Anim. Sci. 69 (1991) 25382547.

[233] Veselsky L., Cechova D., Jonakova V., Secretion and immunochemical properties of the trypsin inhibitor from bovine colostrum, Hoppe Seylers Z. Physiol. Chem. 359 (1978) 873-878.

[234] Wagner C.L., Forsythe D.W., Pittard W.B., Variation in the biochemical forms of transforming growth factor-alpha present in human milk and secreted by human milk macrophages, Biol. Neonate 68 (1995) 325-333.

[235] Xian C.J., Shoubridge C.A., Read L.C., Degradation of IGF-I in the adult rat gastrointestinal tract is limited by a specific antiserum or the dietary protein casein, J. Endocrinol. 146 (1995) 215-225.

[236] Xu R.J., Wang T., Gastrointestinal absorption of insulinlike growth factor-I in neona- tal pigs, J. Pediatr. Gastroenterol. Nutr. 23 (1996) 430-437.

[237] Xu R.J., Mellor D.J., Birtles M.J., Breier B.H., Gluckman P.D., Effects of oral IGFI or IGF-II on digestive organ growth in newborn piglets, Biol. Neonate 66 (1994) 280-287.

[238] Yagi H., Suzuki S., Noji T., Nagashima K., Kuroume T., Epidermal growth factor in cow's milk and milk formulas, Acta Paediatr. Scand. 75 (1986) 233-235.

[239] Yamamura J., Takada Y., Goto M., Kumegawa M., Aoe S., Bovine milk kininogen fragment 1.2 promotes the proliferation of osteoblastic MC3T3-E1 cells, Biochem. Biophys. Res. Commun. 269 (2000) 628-632.

[240] Yamanaka H., Hagiwara K., Kirisawa R., Iwai H., Proinflammatory cytokines in bovine colostrum potentiate the mitogenic response of peripheral blood mononuclear cells from newborn calves through IL-2 and CD25 expression, Microbiol. Immunol. 47 (2003) 461-468.

[241] Young G.P., Taranto T.M., Jonas H.A., Cox A.J., Hogg A., Werther G.A., Insulinlike growth factors and the developing and mature rat small intestine: receptors and biological actions, Digestion 46 (Suppl. 2) (1990) 240-252. 